\title{
Results of Test-Hole Drilling in Well-Field Areas North of Tampa, Florida
}

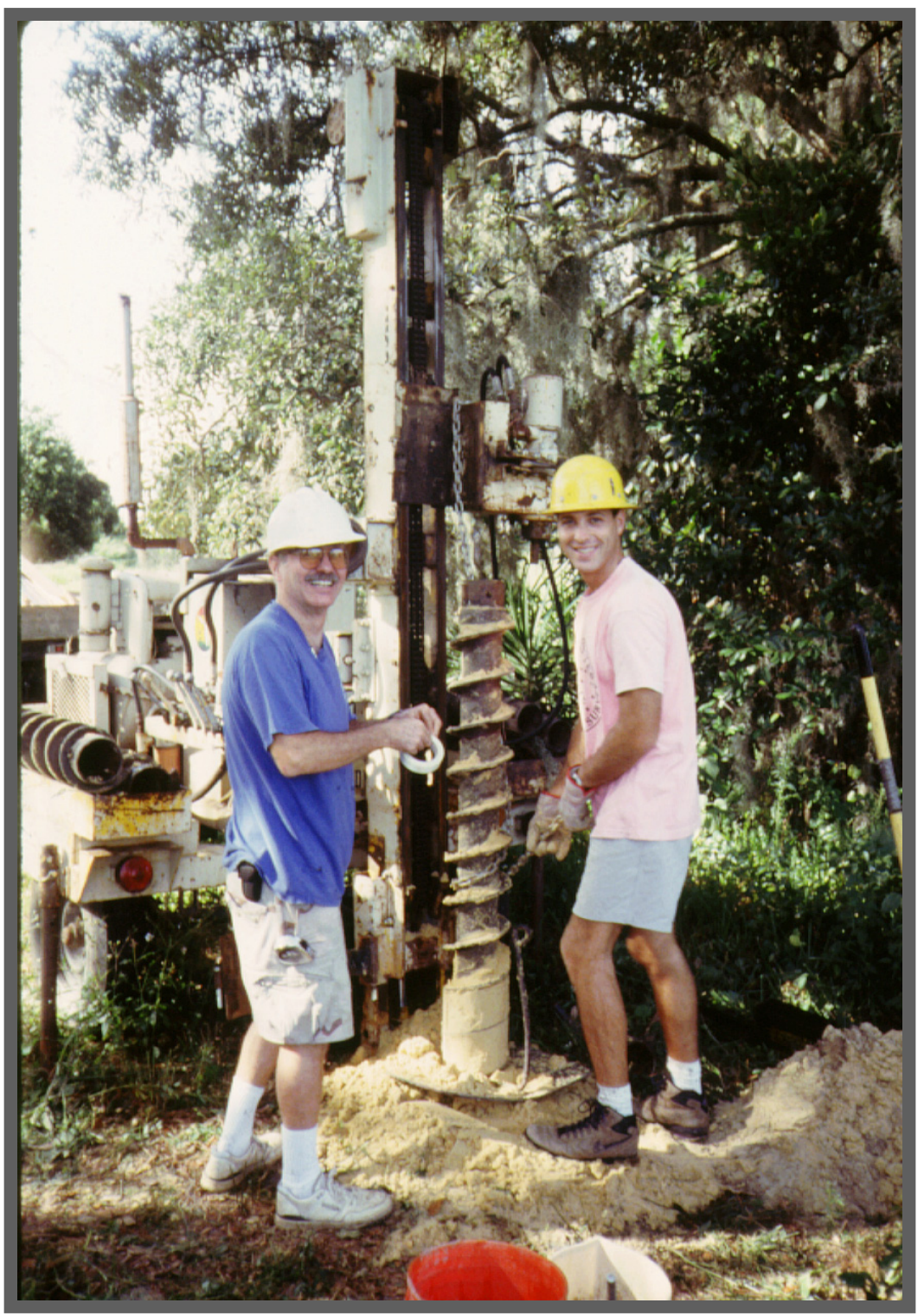

U.S. GEOLOGICAL SURVEY

Open-File Report 03-142

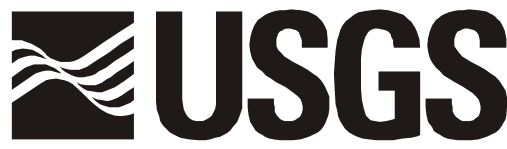

Prepared in cooperation with the

Southwest Florida Water Management District 


\section{Results of Test-Hole Drilling in Well-Field Areas North of Tampa, Florida}

By C.B. Hutchinson

U.S. GEOLOGICAL SURVEY

Open-File Report 03-142

Prepared in cooperation with the

Southwest Florida Water Management District

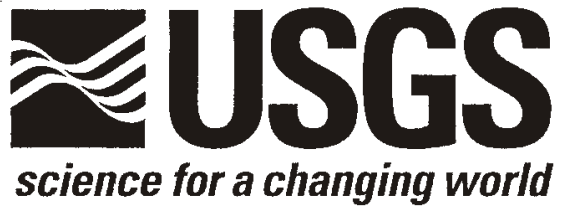

Tallahassee, Florida 


\section{U.S. DEPARTMENT OF INTERIOR \\ GALE A. NORTON, Secretary \\ U.S. GEOLOGICAL SURVEY \\ CHARLES G. GROAT, Director}

The use of firm, trade, or brand names in this report is for identification purposes only and does not constitute endorsement by the U.S. Geological Survey

For additional information about

Florida USGS publications, contact:

U.S. Geological Survey

2010 Levy Avenue

Tallahassee, Florida 32303

(850) 942-9500
For additional information about other USGS publications, contact:

U.S. Geological Survey

Branch of Information Services

Box 25286

Denver CO 80225-0286

888-ASK-USGS

Information about water resources in Florida is available on the Internet at http://fl.water.usgs.gov 


\section{CONTENTS}

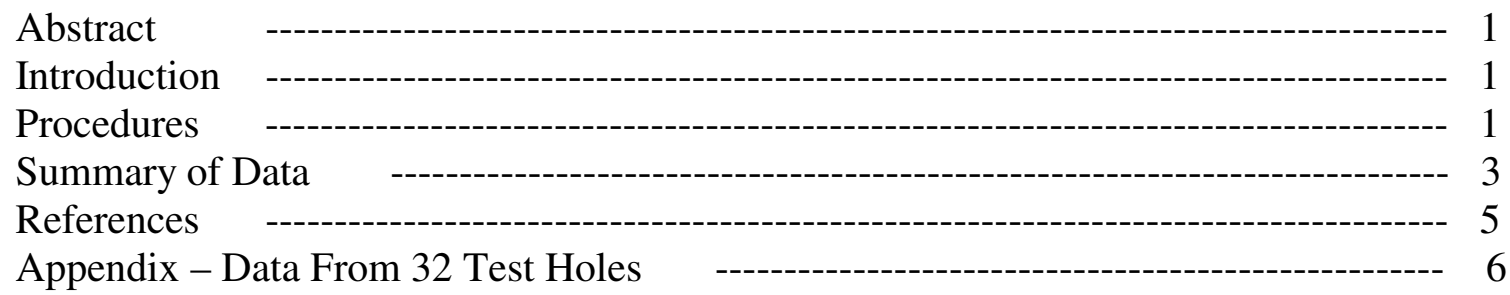

\section{FIGURES}

1. Map showing locations of test holes in Hillsborough, Pasco, and Pinellas

\section{DATUM}

Vertical coordinate information is referenced to National Geodetic Vertical Datum of 1929 (NGVD of 1929); Horizontal coordinate information is referenced to the North American Datum of 1927 (NAD27) 


\title{
RESULTS OF TEST-HOLE DRILLING IN WELL-FIELD AREAS NORTH OF TAMPA, FLORIDA
}

\author{
By C.B. Hutchinson
}

\begin{abstract}
A total of 32 test holes were drilled in well-field areas of Hillsborough, Pasco, and Pinellas Counties in the early 1970's to collect information on the hydraulic and geologic properties of shallow formations overlying the Upper Floridan aquifer. Lithologic profiles were compiled and geohydrologic units identified for each test hole. At most test holes, natural-gamma logs were run to identify the confining unit that separates the surficial aquifer system from the Upper Floridan aquifer. Selected core samples were analyzed in the laboratory for vertical hydraulic conductivity, grain size, sorting, specific gravity, effective porosity, cation-exchange capacity, and mineralogy. Following drilling, casing was installed in each test hole and water levels were monitored. The data were used in the preparation of regional water-level maps and in the construction of a numerical model of ground-water flow in the well-field areas.

\section{INTRODUCTION}

Between November 1971 and February 1974, the U.S. Geological Survey (USGS) drilled 32 test holes in or near well-field areas north of Tampa, Florida (fig. 1). The test holes were drilled in cooperation with the Southwest Florida Water Management District to collect data on the hydraulic and geologic properties of shallow formations overlying the Upper Floridan aquifer. This information was used to prepare quarterly maps of water-levels and head changes in the well-field areas during the 1970's as well as a ground-water model of the well-field areas during the 1980's (Hutchinson and Mills, 1977; Hutchinson, 1984).

The purpose of this report is to present data from the test-drilling phase. Data are included for 32 test holes drilled within a 600-square-mile area of Hillsborough, Pasco, and Pinellas Counties. The report includes geophysical and lithologic logs, and laboratory test results. Data were collected in the early 1970's, before the advent of personal computers, and remained in the author's files for nearly 30 years. The paper files of lithologic and natural-gamma logs and the location map were transferred to digital format by Dann Yobbi and Lari Knochenmus (USGS Tampa) and the author gratefully recognizes their contributions.
\end{abstract}

\section{PROCEDURES}

A hollow-stem auger was used to bore shallow test holes, generally less than 100feet deep. Split-spoon samples of the formations, 1.5-feet long and 1-inch in diameter, were collected at 5-foot intervals. Selected 6-inch core samples were collected in metal sleeves and sent to the USGS hydrologic laboratory in Denver, Colorado, for analysis of mineralogy, grain size, sorting, specific gravity, hydraulic conductivity, porosity, and cation-exchange capacity. At each test-hole site, two 2-inch PVC wells with about 5 feet 
of screen were usually installed; one near the bottom of the surficial aquifer system and a second near the top of the Upper Floridan aquifer. A natural-gamma log was usually run in the Upper Floridan aquifer well to verify the top and bottom of the confining unit that separates the two aquifers. The drilling logs, well schedules, laboratory test results, and geophysical logs are located in files of the USGS office in Tampa, Florida.

\section{EXPLANATION}

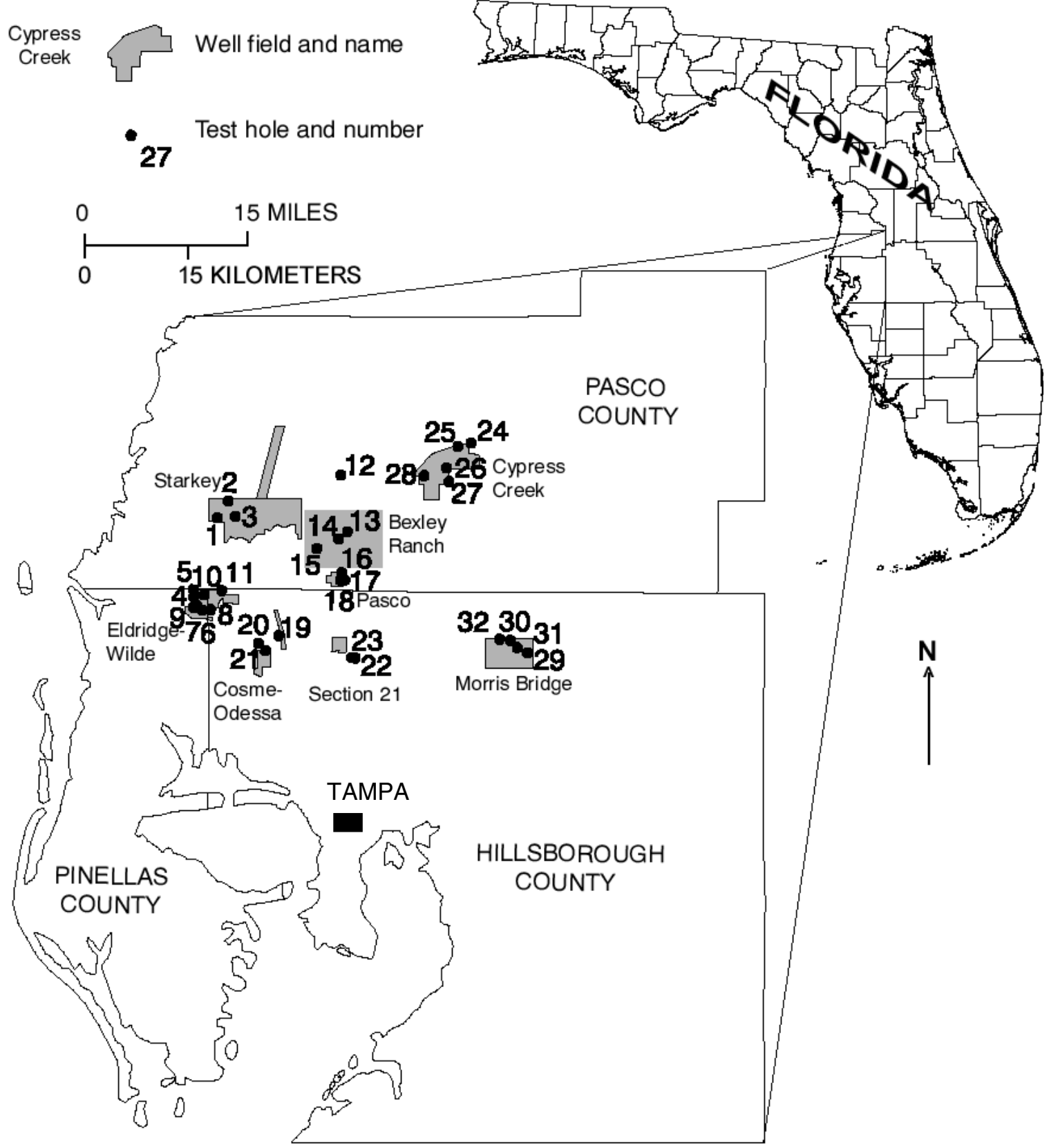

Figure 1. Locations of test holes in Hillsborough, Pasco, and Pinellas Counties, Florida. 


\section{SUMMARY OF DATA}

Data from 32 test holes are presented in diagrams in the appendix. Some diagrams are complete with lithologic log, natural-gamma log, and laboratory test results. In several of the test holes, natural-gamma logs or laboratory tests were not conducted. Data include the following:

Location - The test holes were located on aerial topographic maps provided by the Southwest Florida Water Management District. Locations were transferred from the aerial maps to USGS 7.5-minute topographic quadrangle maps for calculation of latitude and longitude coordinates in minutes, degrees, and seconds. Location also is presented as quarter(1/4)-section(S)-township(T)-range(R).

Field number - Each well is identified by a field number, which consists of a name and number. Most wells are numbered consecutively in sets of 100. For example, test-hole 1 , with a field number of Starkey 728 , is in the Starkey well field and is the $29^{\text {th }}$ well in the $7^{\text {th }}$ field notebook. It is the $29^{\text {th }}$ well because the first well is number 700 . The exceptions are test holes 6 and 7 in the Eldridge-Wilde well field with field numbers of Eldridge-Wilde $5 \mathrm{~N}$ and 7, which correspond with production well numbers. Note also that Eldridge-Wilde well field contains wells in the first and second field notebooks, with numbers between 001 and 200.

Altitude of land surface - Altitude of land surface at each test-hole site relative to the National Geodetic Vertical Datum of 1929 (NGVD of 1929) was estimated from an instrument survey of the top of the well casing, which is generally to the nearest hundredth of a foot above sea level. For example, if a well casing rises 1.3 feet above land surface to a level of 34.04 feet above NGVD of 1929, land surface would be estimated at 32.7 feet above NGVD of 1929.

Lithology - A lithologic description was compiled from visual inspection of core samples collected in each test hole. Grain size was estimated by comparing the sample with standards based on the Wentworth scale. Color description is from field comparison of samples with the standard Geologic Society of America rock-color chart. Horizontal gray lines separate zones of lithologic and color changes.

Geohydrologic unit - Three geohydrologic units are generally recognized in the study area: the surficial aquifer system, the confining unit, and the Upper Floridan aquifer. The three units were identified using lithologic and geophysical data and are separated by black lines on the diagrams.

Natural-gamma log - Clay and phosphate are emitters of gamma rays in the subsurface in west-central Florida. The natural-gamma geophysical log counts emissions and scribes them on a graph. The natural-gamma log combined with lithologic data is a good indicator of the position of the confining unit, which is composed mainly of clay, because this clay typically has higher radiation readings than surrounding units. For some logs, 
the reading goes beyond the right end of the horizontal axis scale and "wraps" back to the left.

Vertical hydraulic conductivity - Vertical hydraulic conductivity was measured in the laboratory by the falling-head permeameter method. Test samples were cores collected vertically in metal sleeves, therefore, the rate of water flow through each sleeve measured the vertical hydraulic conductivity of the sample. Vertical hydraulic conductivity of the confining unit is an important hydraulic parameter in ground-water models. The vertical hydraulic conductivity is a controlling factor in movement of water between the surficial aquifer system and the Upper Floridan aquifer.

Median-grain size - Median-grain size is based on sieve analysis, and along with sorting coefficient, can be used to estimate hydraulic conductivity.

Sorting coefficient - A sorting coefficient of 1 represents uniform material; greater than 1 represents nonuniformity. Sorting can affect the flow of water through a formation. Poorly sorted formations have small particles in the interstices that restrict flow and reduce hydraulic conductivity.

Specific gravity of solids - The major mineral components of the geologic system include quartz, clay minerals, and calcite. The specific gravity of each component is distinctive and can be used to confirm mineralogy from visual estimates and geophysical logs.

Effective porosity - Effective porosity was measured by drying each saturated sample at 150 degrees Fahrenheit, measuring the reduction in weight, and attributing the difference to pore space. Effective porosity is another important parameter used in ground-water modeling.

Cation-exchange capacity - Dissolved cations may be adsorbed to negatively charged areas in the crystal lattice of clay minerals or exchanged with existing adsorbed cations. Factors for converting grams to milliequivalents are presented in Hem (1970). This parameter has been used to calculate the absorption capacity of the confining unit at a landfill site (Hutchinson and Stewart, 1978), thereby measuring its capacity for preventing contamination of the Upper Floridan aquifer by downward movement of pollutants.

Mineralogy - Percentages of quartz, calcite, feldspar, kaolinite, illite, montmorillonite, and mixed-layer clays were estimated using x-ray diffraction analysis. Quartz is the main mineral in the surficial aquifer system, clay minerals characterize the confining unit, and calcite dominates in the Upper Floridan aquifer. 


\section{REFERENCES}

Hem, J.D., 1970, Study and interpretation of chemical characteristics of natural water, (2d ed.): U.S. Geological Survey Water-Supply Paper 1473, 363 p.

Hutchinson, C.B., 1984, Hydrogeology of well-field areas near Tampa, Florida, Phase 2--Development and documentation of a quasi-three-dimensional finitedifference model for simulation of steady-state ground-water flow: U.S. Geological Survey Water-Resources Investigations Report 84-4002, 174 p.

Hutchinson, C.B., and Mills, L.R., 1977, Water table in the surficial aquifer and potentiometric surface of the Floridan aquifer in selected well fields, west-central Florida, May 1976: U. S. Geological Survey Open-File Report 77-0257, 4 sheets.

Hutchinson, C.B., Stewart, J.W., 1978, Geohydrologic evaluation of a landfill in a coastal area, St. Petersburg, Florida: U.S. Geological Survey Water-Resources Investigations Report 77-78, 40 p. 
APPENDIX

DATA FROM 32 TEST HOLES 


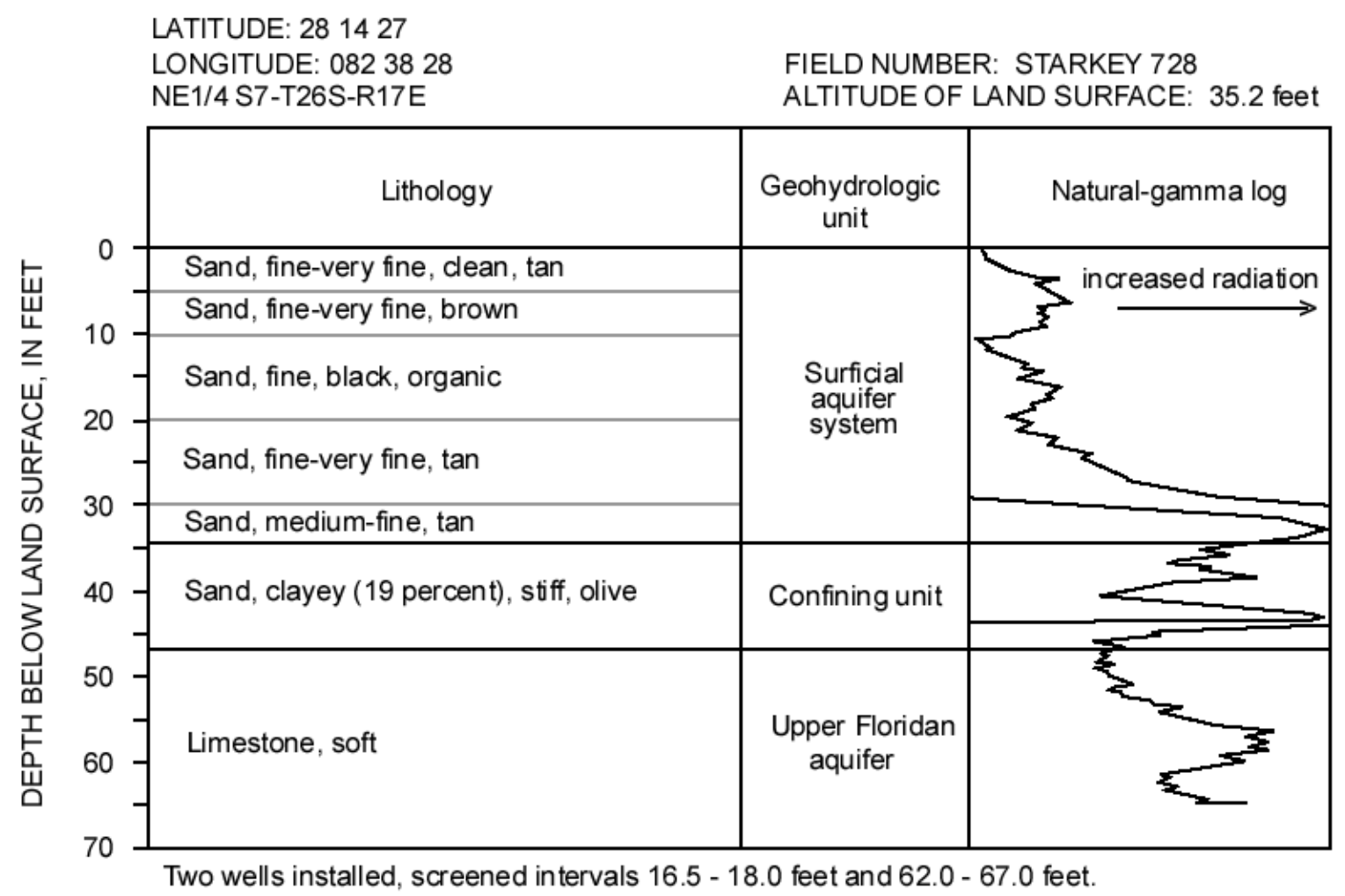

Laboratory test results

\begin{tabular}{l|c|c}
\hline \multirow{2}{*}{ Parameter } & \multicolumn{2}{|c}{ Sample depth (feet) } \\
\cline { 2 - 3 } & $27.0-27.5$ & $37.0-37.5$ \\
\hline Vertical hydraulic conductivity (m/d) & 1.24 & 0.018 \\
Median-grain size (mm) & .15 & .13 \\
Sorting coefficient & 1.4 & 2.2 \\
Specific gravity of solids & 2.67 & 2.64 \\
Effective porosity (percent) & 34.2 & 25.3 \\
Cation exchange capacity (MEQ/100g) & -- & -- \\
Quartz (percent) & -- & 67 \\
Calcite (percent) & -- & 0 \\
Feldspar (percent) & -- & 0 \\
Kaolinite (percent) & -- & 5 \\
Illite (percent) & -- & 0 \\
Montmorillonite (percent) & -- & 0 \\
Mixed-layer clays (percent) & -- & 25 \\
\hline
\end{tabular}

[m/d, meters per day; mm, millimeters; MEQ, milliequivalents; g, grams] 


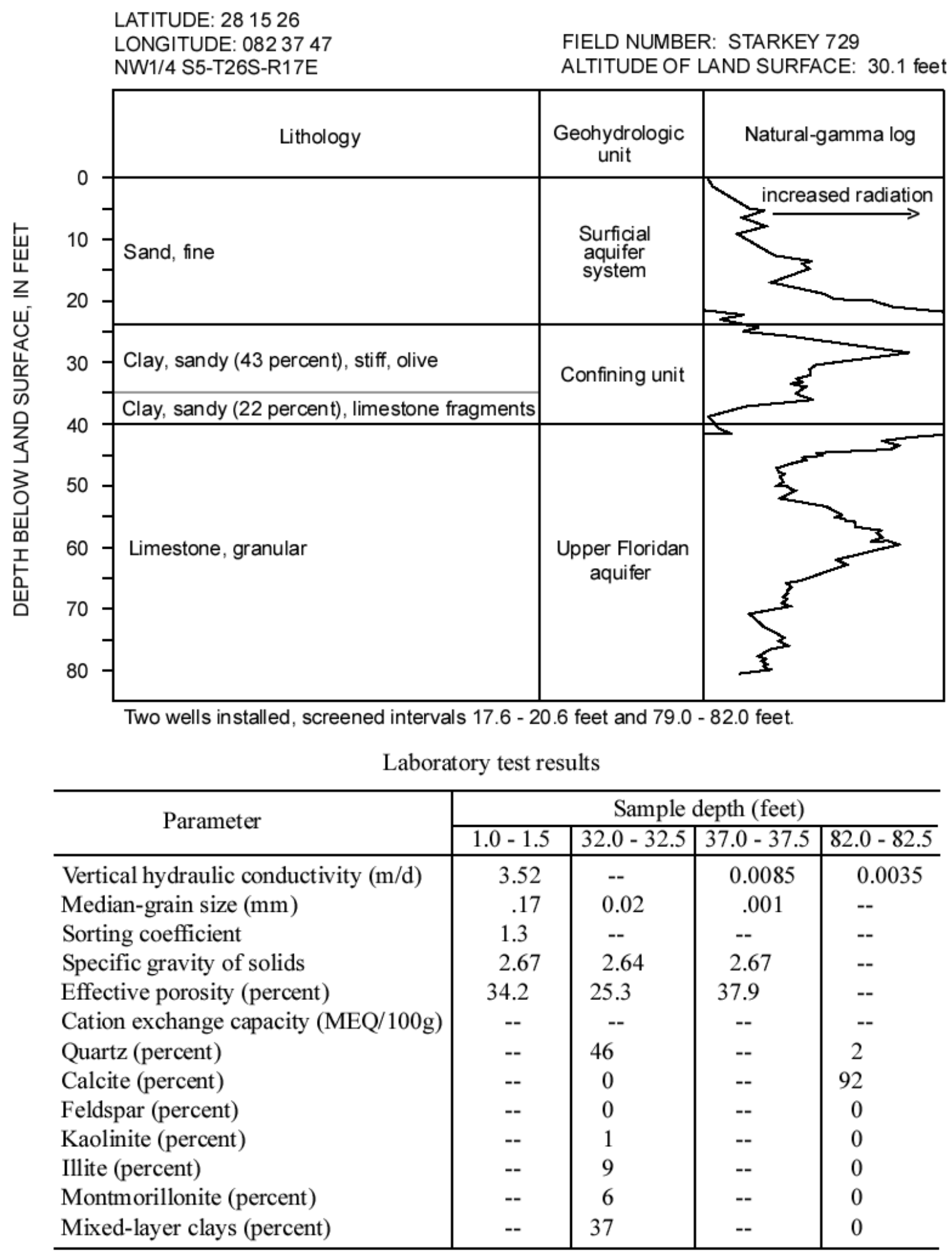

[m/d, meters per day; mm, millimeters; MEQ, milliequivalents; g, grams; --, no data] 
TEST-HOLE NUMBER 3

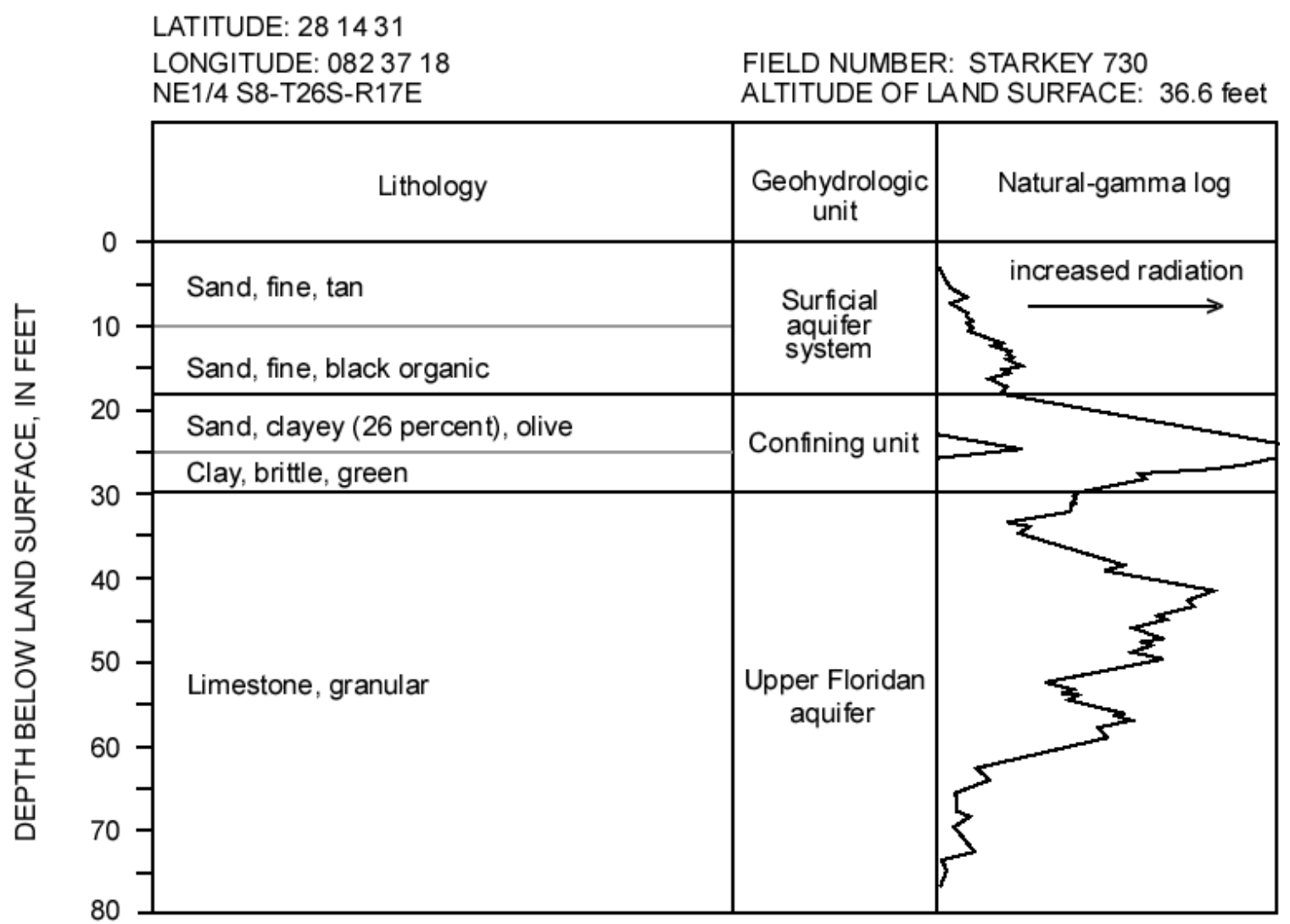

Two wells installed, screened intervals $14.4-17.4$ feet and $77.0-82.0$ feet.

Laboratory test results

\begin{tabular}{l|c|c|c|c}
\hline \multirow{2}{*}{\multicolumn{1}{c|}{ Parameter }} & \multicolumn{4}{c}{ Sample depth (feet) } \\
\cline { 2 - 5 } & $1.0-1.5$ & $22.0-22.5$ & $27.0-27.5$ & $32.0-32.5$ \\
\hline Vertical hydraulic conductivity (m/d) & 5.29 & 0.0002 & 0.0004 & 0.0053 \\
Median-grain size (mm) & .17 & -1 & .001 & -- \\
Sorting coefficient & 1.3 & -- & -- & -- \\
Specific gravity of solids & 2.68 & 2.69 & 2.66 & -- \\
Effective porosity (percent) & 36.7 & 22.8 & 22.5 & -- \\
Cation exchange capacity (MEQ/100g) & -- & -- & -- & -- \\
Quartz (percent) & -- & -- & 13 & 1 \\
Calcite (percent) & -- & -- & 0 & 89 \\
Feldspar (percent) & -- & -- & 0 & 0 \\
Kaolinite (percent) & -- & -- & 0 & 0 \\
Illite (percent) & -- & -- & 30 & 0 \\
Montmorillonite (percent) & -- & -- & 33 & 0 \\
Mixed-layer clays (percent) & -- & -- & 16 & 0 \\
\hline
\end{tabular}

[m/d, meters per day; mm, millimeters; MEQ, milliequivalents; g, grams; --, no data] 


\section{TEST-HOLE NUMBER 4}

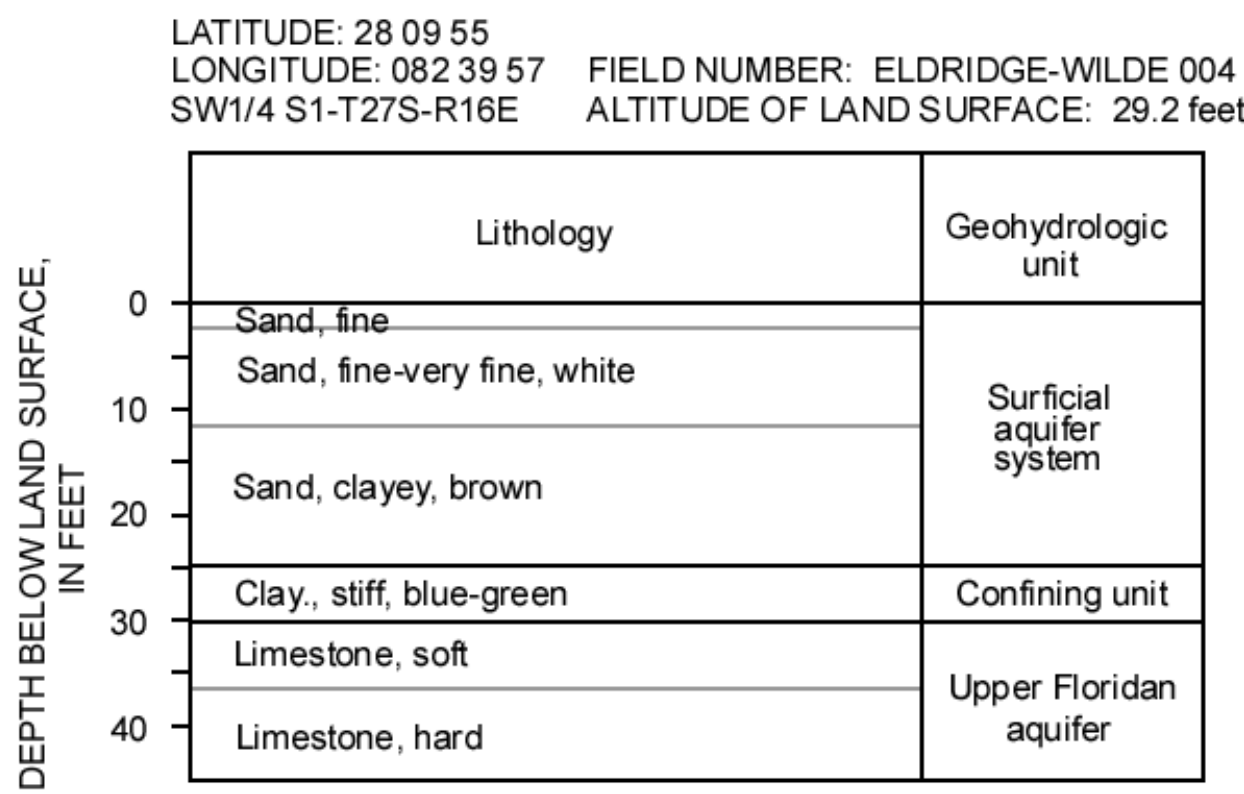

Two wells installed, screened intervals $16.0-18.0$ feet and $40.5-42.0$ feet. 
TEST-HOLE NUMBER 5

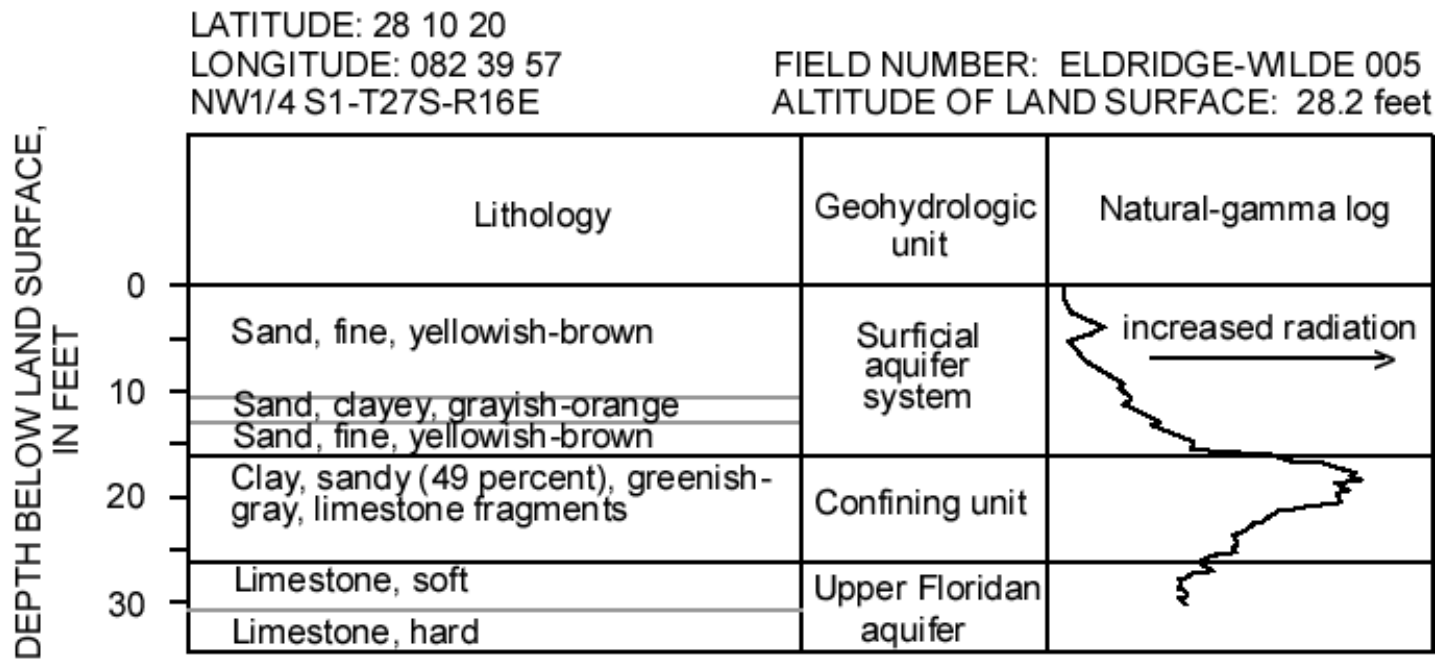

Two wells installed, screened intervals $17.5-19.0$ feet and $30.5-32.0$ feet.

Laboratory test results

\begin{tabular}{l|c}
\hline \multirow{2}{*}{ Parameter } & Sample depth (feet) \\
\cline { 2 - 2 } & $21.0-21.5$ \\
\hline Vertical hydraulic conductivity (m/d) & 0.00005 \\
Median-grain size (mm) & .04 \\
Sorting coefficient & 2.63 \\
Specific gravity of solids & 22.5 \\
Effective porosity (percent) & 11 \\
Cation exchange capacity (MEQ/100g) & 51 \\
Quartz (percent) & 0 \\
Calcite (percent) & 0 \\
Feldspar (percent) & 14 \\
Kaolinite (percent) & 15 \\
Illite (percent) & 0 \\
Montmorillonite (percent) & 30 \\
Mixed-layer clays (percent) & \\
\hline
\end{tabular}

[m/d, meters per day; mm, millimeters; MEQ, milliequivalents; $\mathrm{g}$, grams; --, no data] 
TEST-HOLE NUMBER 6

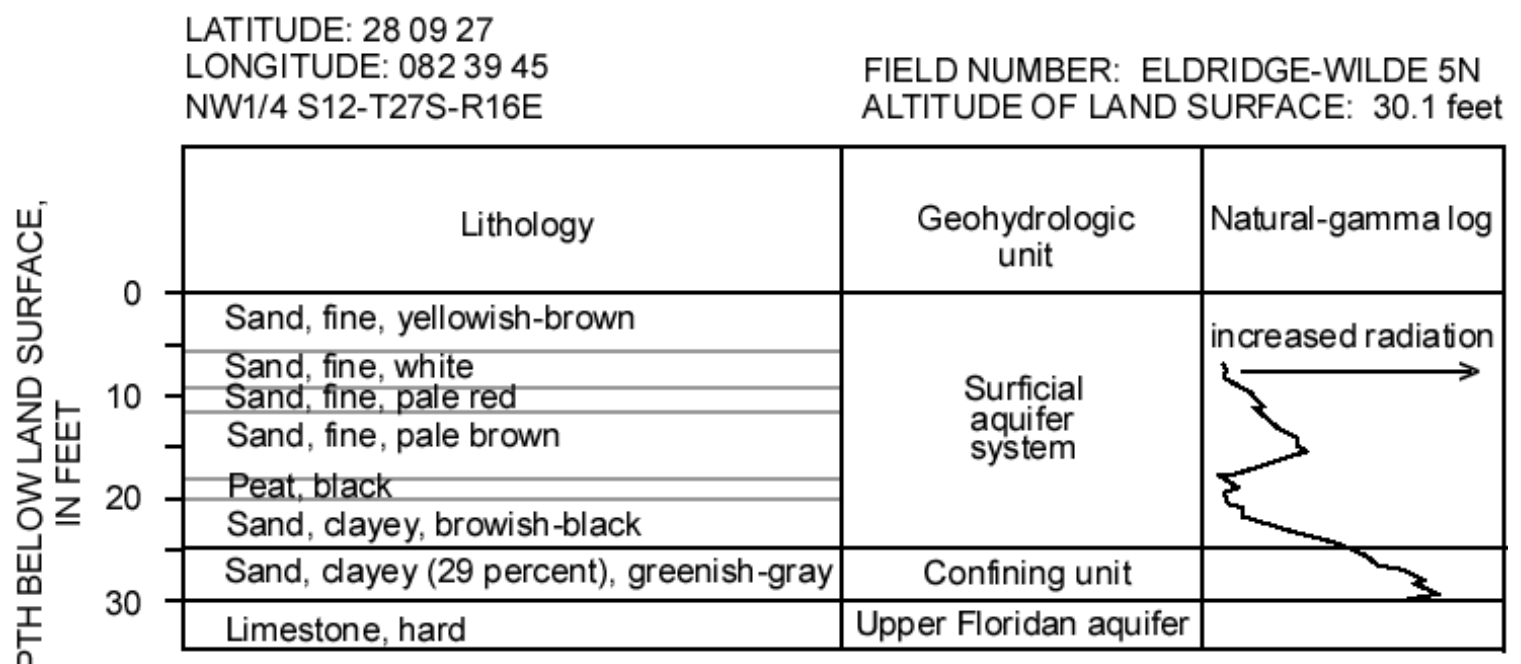

Two wells installed, screened intervals $14.5-16.0$ feet and $31.0-33.0$ feet.

Laboratory test results

\begin{tabular}{l|c}
\hline \multirow{2}{*}{ Parameter } & Sample depth (feet) \\
\cline { 2 - 2 } & $29.0-29.5$ \\
\hline Vertical hydraulic conductivity (m/d) & 0.0001 \\
Median-grain size (mm) & .09 \\
Sorting coefficient & -- \\
Specific gravity of solids & 2.63 \\
Effective porosity (percent) & 31.4 \\
Cation exchange capacity (MEQ/100g) & 17 \\
Quartz (percent) & 54 \\
Calcite (percent) & 0 \\
Feldspar (percent) & 6 \\
Kaolinite (percent) & 0 \\
Illite (percent) & 1 \\
Montmorillonite (percent) & 26 \\
Mixed-layer clays (percent) & 13 \\
\hline
\end{tabular}

[m/d, meters per day; mm, millimeters; MEQ, milliequivalents; g, grams; --, no data] 
TEST-HOLE NUMBER 7

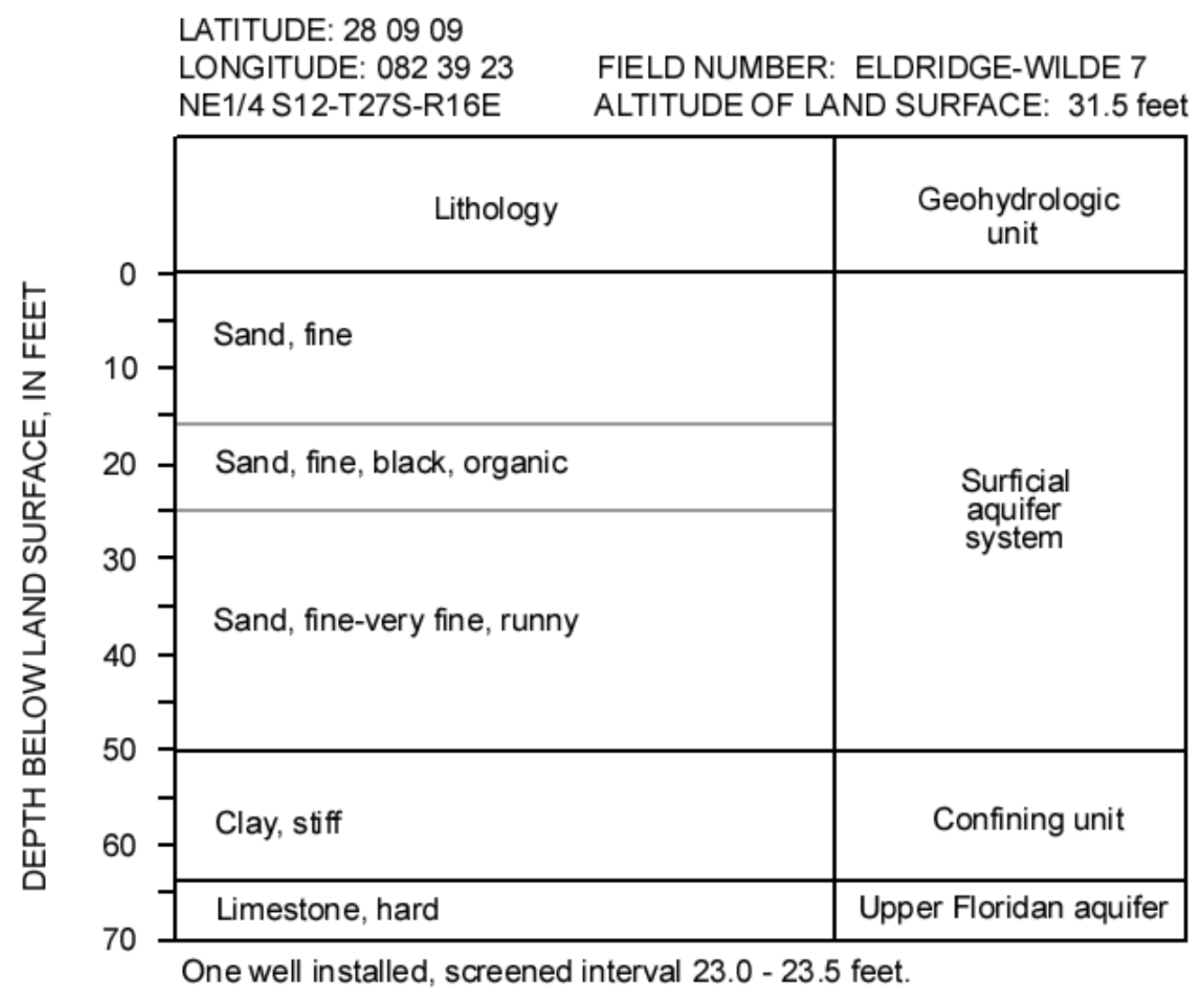

Note: Unable to sample below 25 feet because of runny sand. Hole drilled easily to 64 feet. When augers were pulled, bottom 14 feet were coated with stiff clay. 
TEST-HOLE NUMBER 8

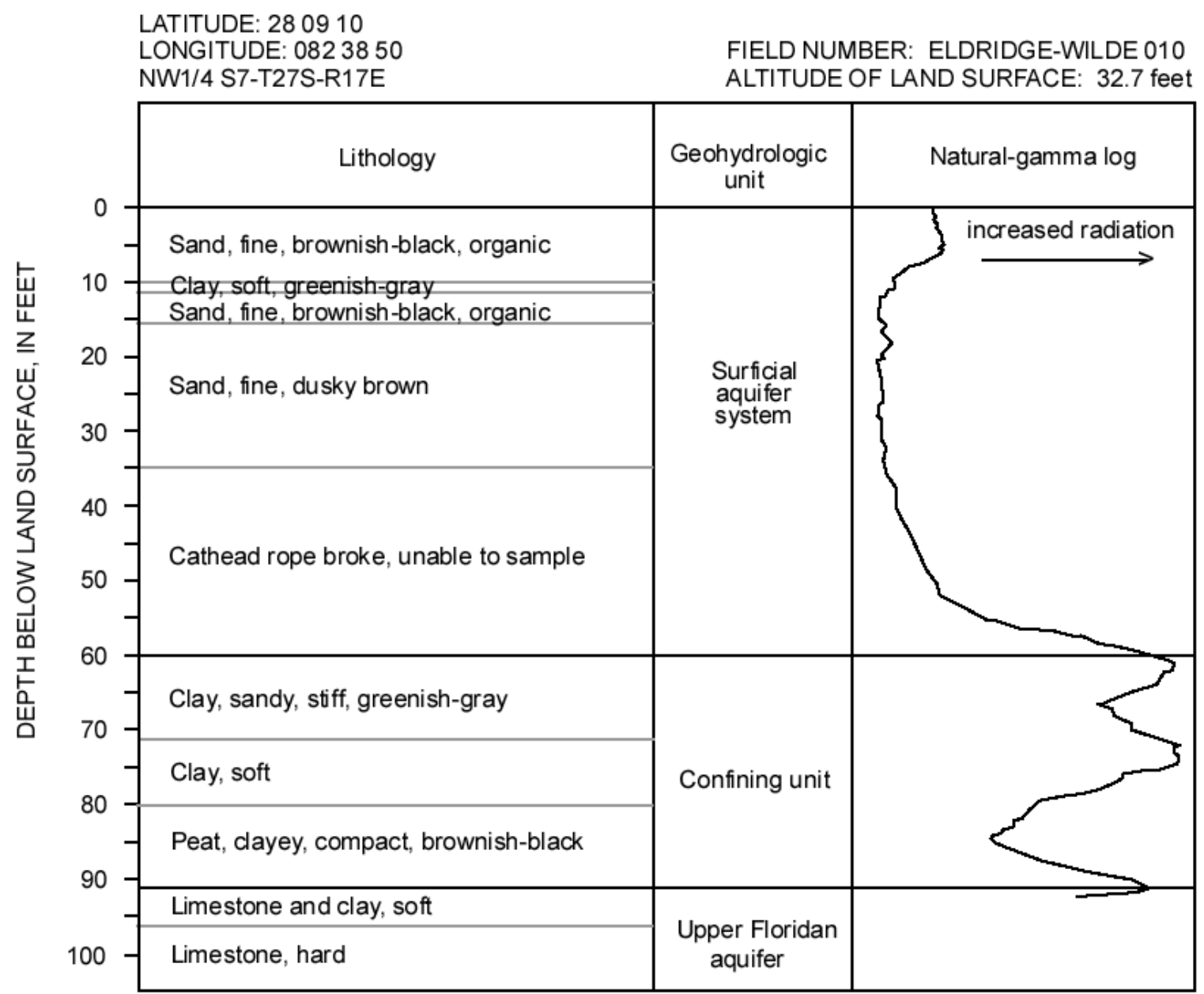

Two wells installed, screened intervals 17.5 - 19.0 feet and 92.0 - 93.5 feet.

Note: Test hole was drilled near the edge of a topographic depression.

Lithology is indicative of a relic sinkhole and may not represent regional conditions. 


\section{TEST-HOLE NUMBER 9}

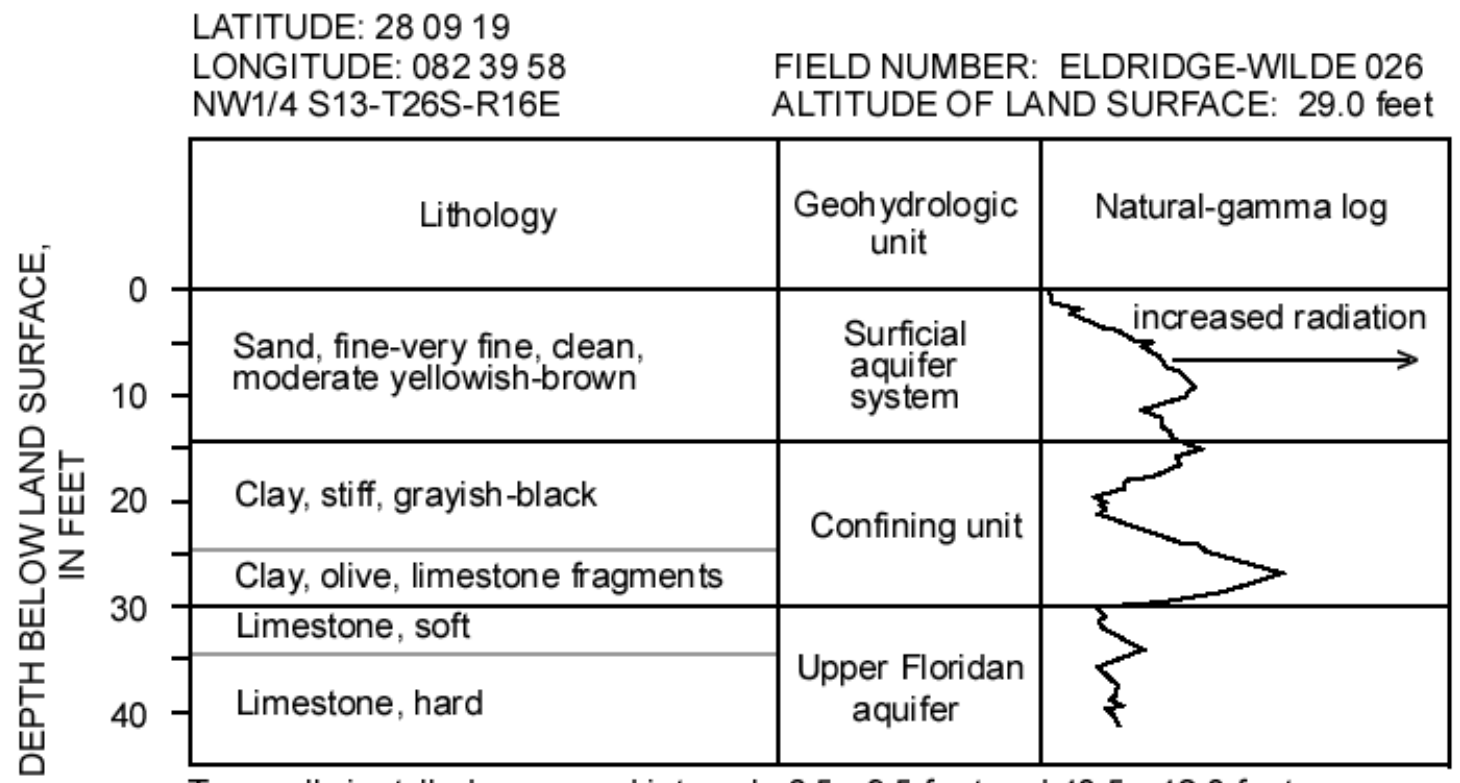

Two wells installed, screened intervals $6.5-9.5$ feet and $40.5-42.0$ feet.

Note: Test hole was drilled in a swampy area. The grayish-black clay (14-24 feet) may be the cause of a locally perched water table. 
TEST-HOLE NUMBER 10

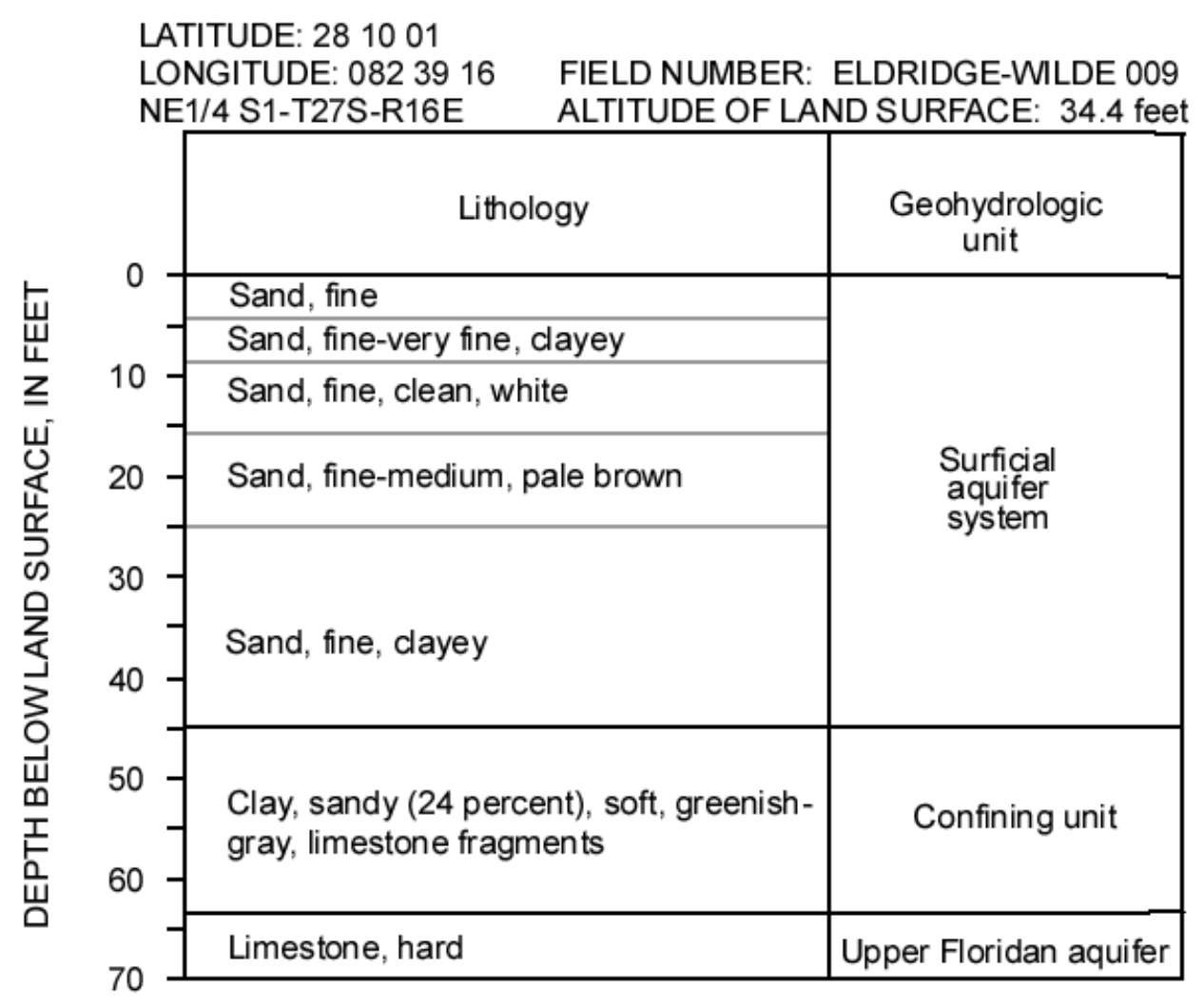

Two wells installed, screened intervals $25.5-27.0$ feet and $51.5-53.0$ feet.

Laboratory test results

\begin{tabular}{l|c}
\hline \multirow{2}{*}{ Parameter } & Sample depth (feet) \\
\cline { 2 - 2 } & $52.0-52.5$ \\
\hline Vertical hydraulic conductivity (m/d) & 0.00003 \\
Median-grain size (mm) & .004 \\
Sorting coefficient & -- \\
Specific gravity of solids & 2.66 \\
Effective porosity (percent) & 34.5 \\
Cation exchange capacity (MEQ/100g) & -- \\
Quartz (percent) & 18 \\
Calcite (percent) & 47 \\
Feldspar (percent) & 2 \\
Kaolinite (percent) & 0 \\
Illite (percent) & 0 \\
Montmorillonite (percent) & 6 \\
Mixed-layer clays (percent) & 9 \\
\hline
\end{tabular}

[m/d, meters per day; mm, millimeters; MEQ, milliequivalents; g, grams; --, no data] 


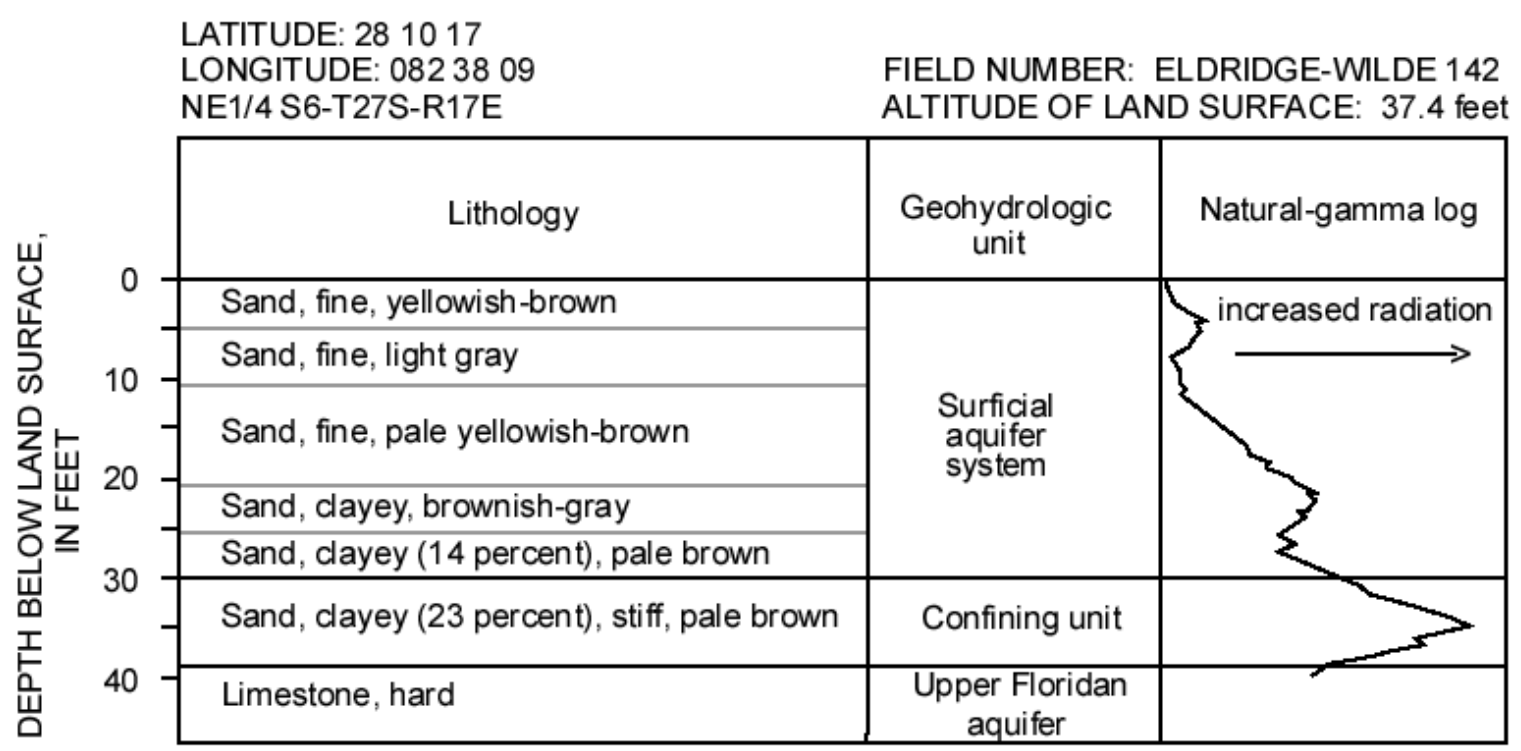

Two wells installed, screened intervals $10.0-13.0$ feet and $38.0-39.0$ feet.

Laboratory test results

\begin{tabular}{l|c|c}
\hline \multirow{2}{*}{ Parameter } & \multicolumn{2}{|c}{ Sample depth (feet) } \\
\cline { 2 - 3 } & $28.0-28.5$ & $32.5-33.0$ \\
\hline Vertical hydraulic conductivity (m/d) & 0.17 & 0.000006 \\
Median-grain size (mm) & .12 & .08 \\
Sorting coefficient & 1.7 & 2.9 \\
Specific gravity of solids & 2.62 & 2.62 \\
Effective porosity (percent) & 26.2 & 31.8 \\
Cation exchange capacity (MEQ/100g) & 3.1 & 16 \\
Quartz (percent) & 78 & 51 \\
Calcite (percent) & 0 & 0 \\
Feldspar (percent) & 0 & 7 \\
Kaolinite (percent) & 10 & 0 \\
Illite (percent) & 3 & 3 \\
Montmorillonite (percent) & 0 & 11 \\
Mixed-layer clays (percent) & 7 & 31 \\
\hline
\end{tabular}

[m/d, meters per day; $\mathrm{mm}$, millimeters; MEQ, milliequivalents; $\mathrm{g}$, grams] 
TEST-HOLE NUMBER 12

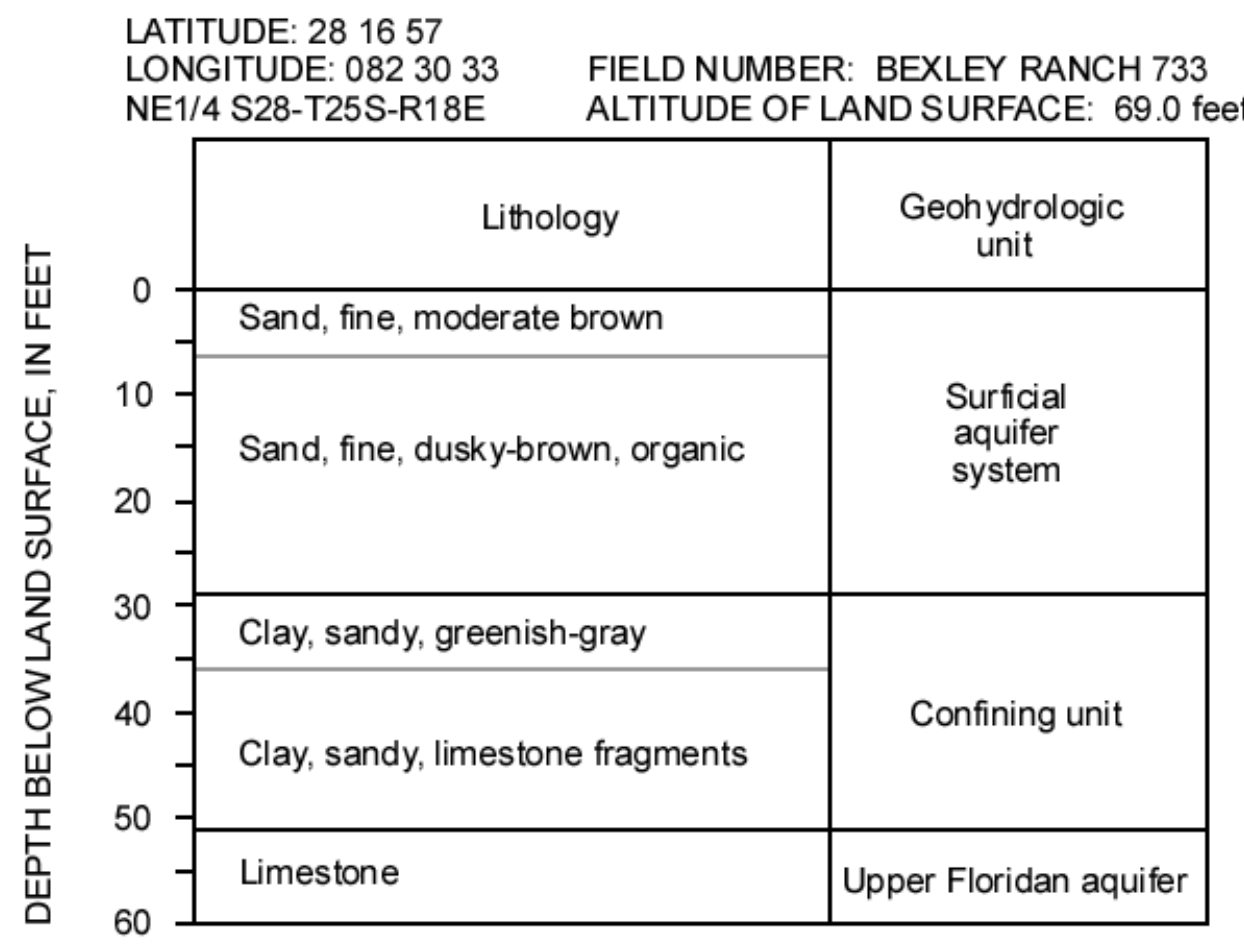

Two wells installed, screened intervals $12.5-13.5$ feet and $53.0-54.5$ feet. 
TEST-HOLE NUMBER 13

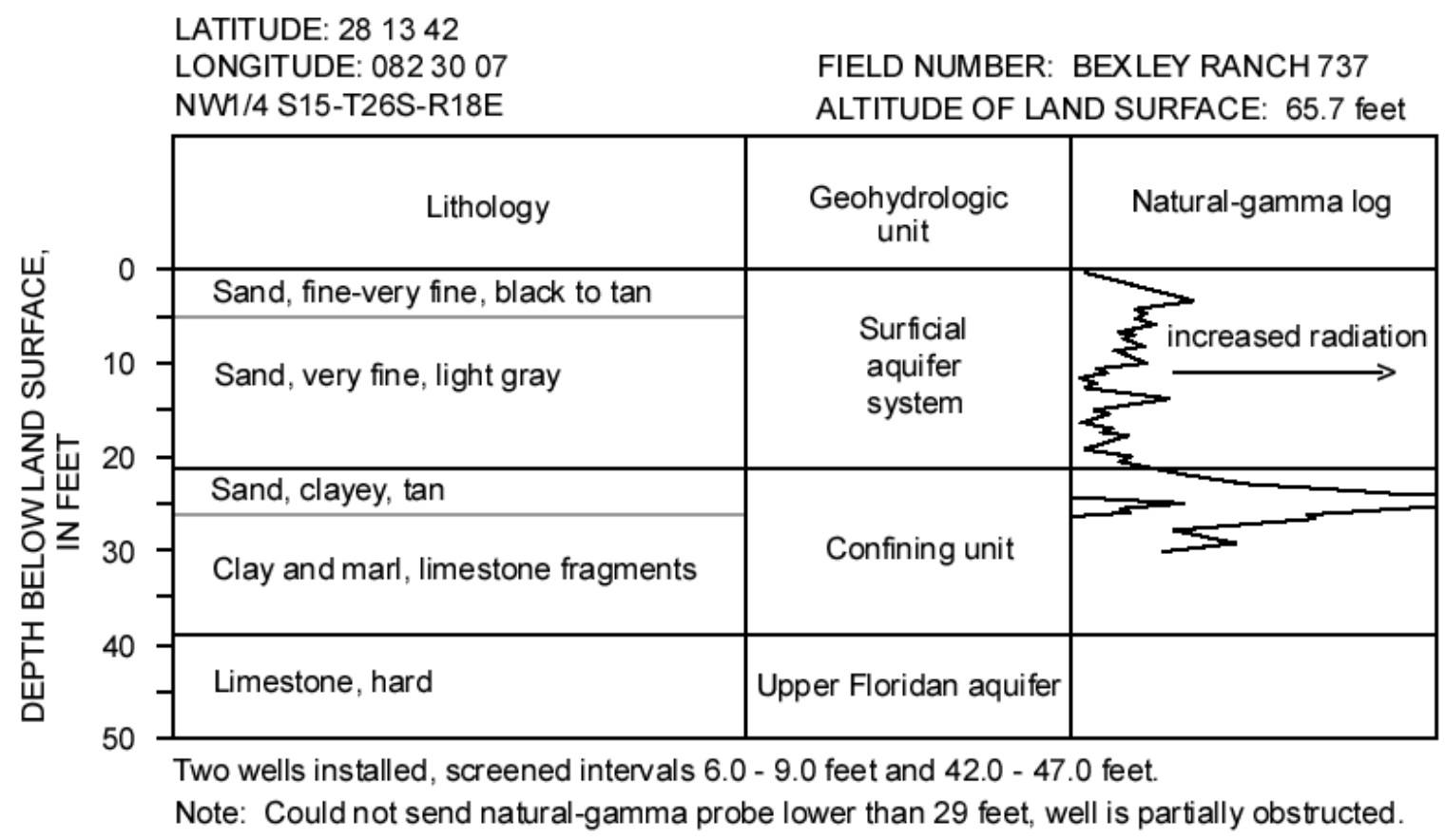




\section{TEST-HOLE NUMBER 14}

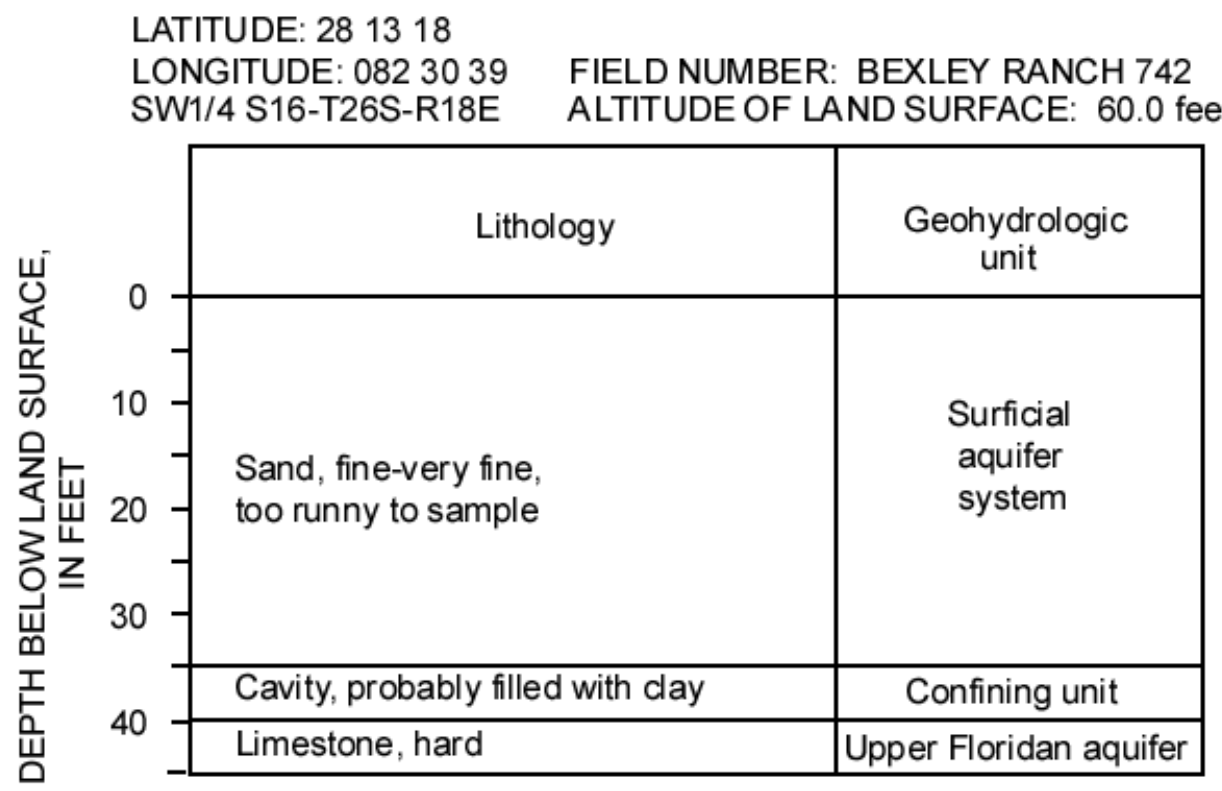

Two wells installed, screened intervals $7.5-8.0$ feet and $41.5-43.0$ feet. 


\section{TEST-HOLE NUMBER 15}

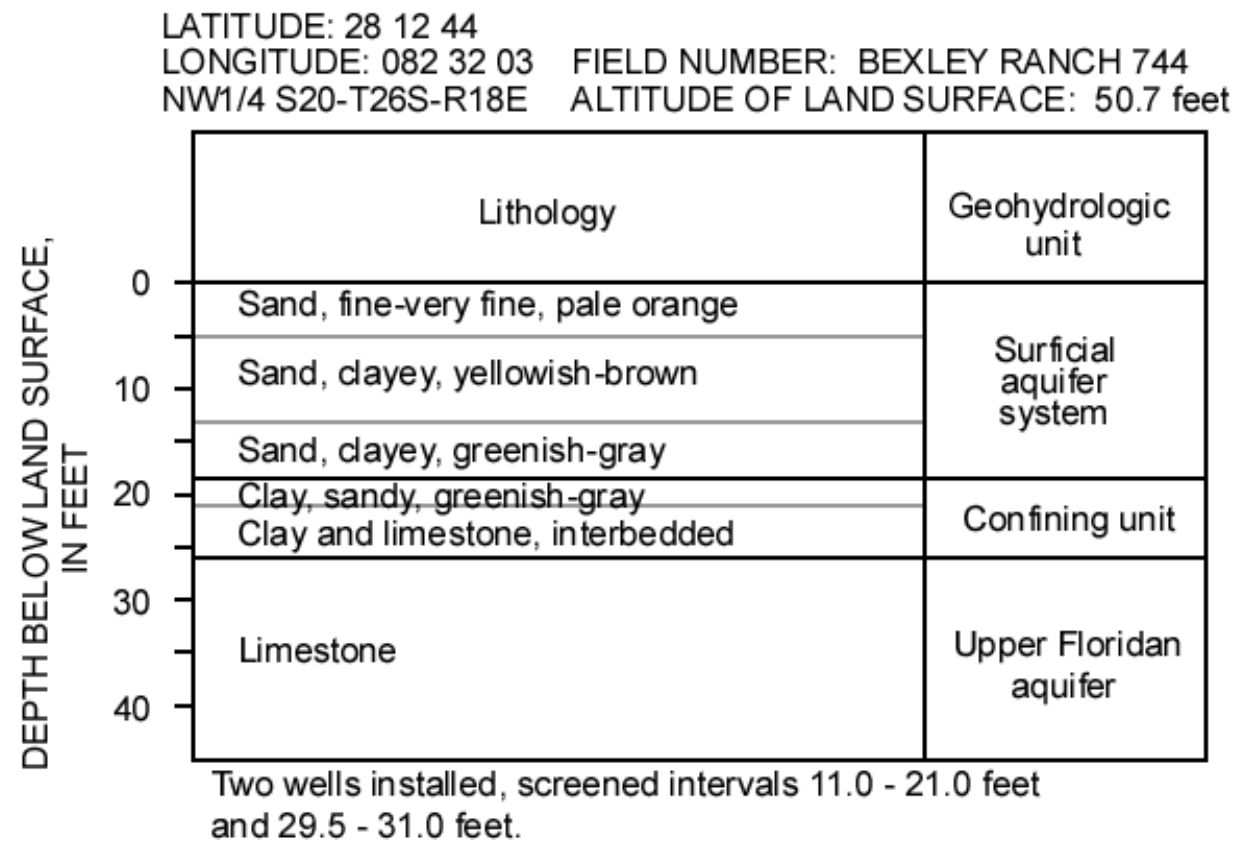




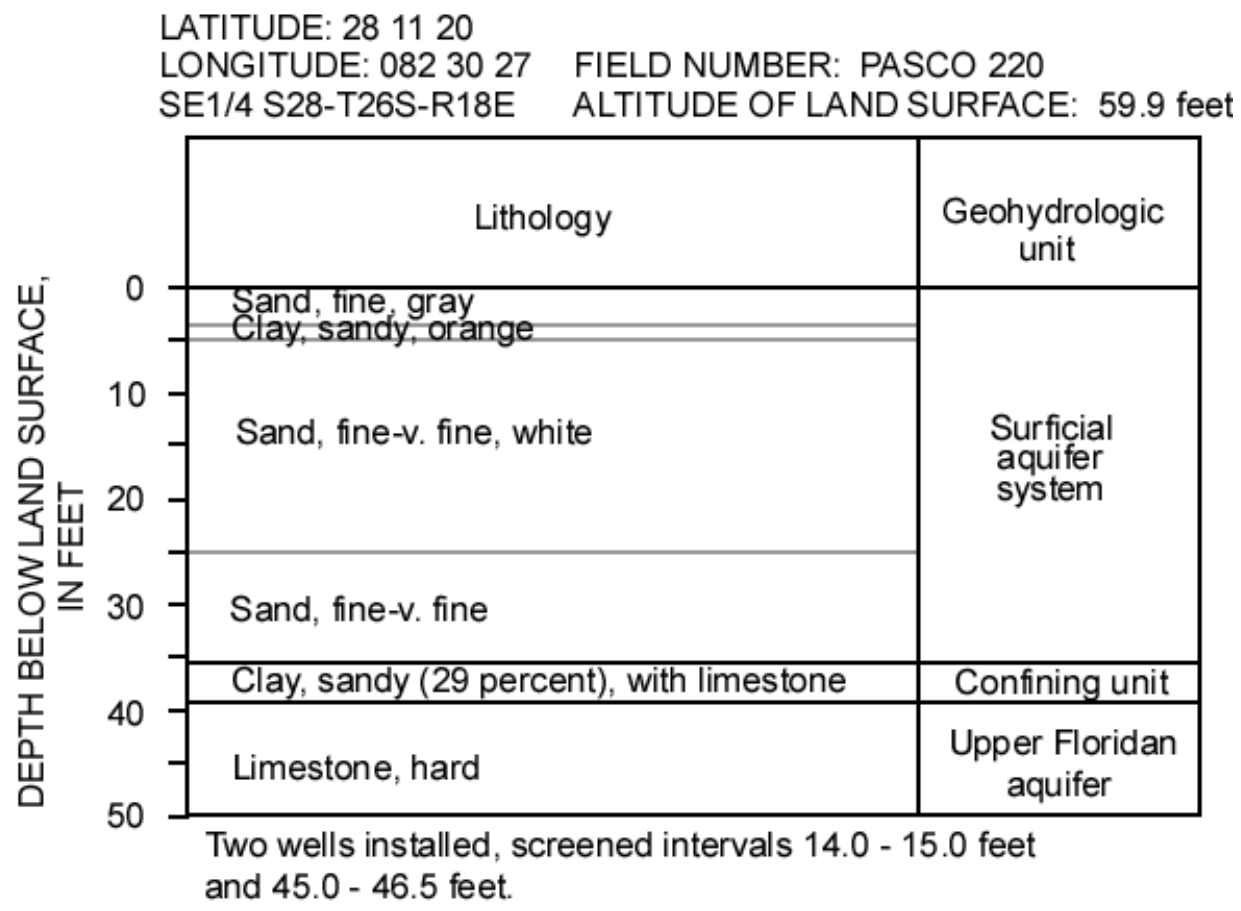

Laboratory test results

\begin{tabular}{l|c|c}
\hline \multirow{2}{*}{ Parameter } & \multicolumn{2}{|c}{ Sample depth (feet) } \\
\cline { 2 - 3 } & $33.0-33.5$ & $37.0-37.5$ \\
\hline Vertical hydraulic conductivity (m/d) & 0.14 & 0.00023 \\
Median-grain size (mm) & .14 & .008 \\
Sorting coefficient & 1.4 & -- \\
Specific gravity of solids & 2.68 & 2.68 \\
Effective porosity (percent) & 33.8 & -- \\
Cation exchange capacity (MEQ/100g) & 2.4 & 6.6 \\
Quartz (percent) & 90 & 13 \\
Calcite (percent) & 0 & 71 \\
Feldspar (percent) & 0 & 0 \\
Kaolinite (percent) & 7 & 0 \\
Illite (percent) & 1 & 0 \\
Montmorillonite (percent) & 2 & 9 \\
Mixed-layer clays (percent) & 0 & 1 \\
\hline
\end{tabular}

[m/d, meters per day; mm, millimeters; MEQ, milliequivalents; g, grams; --, no data] 


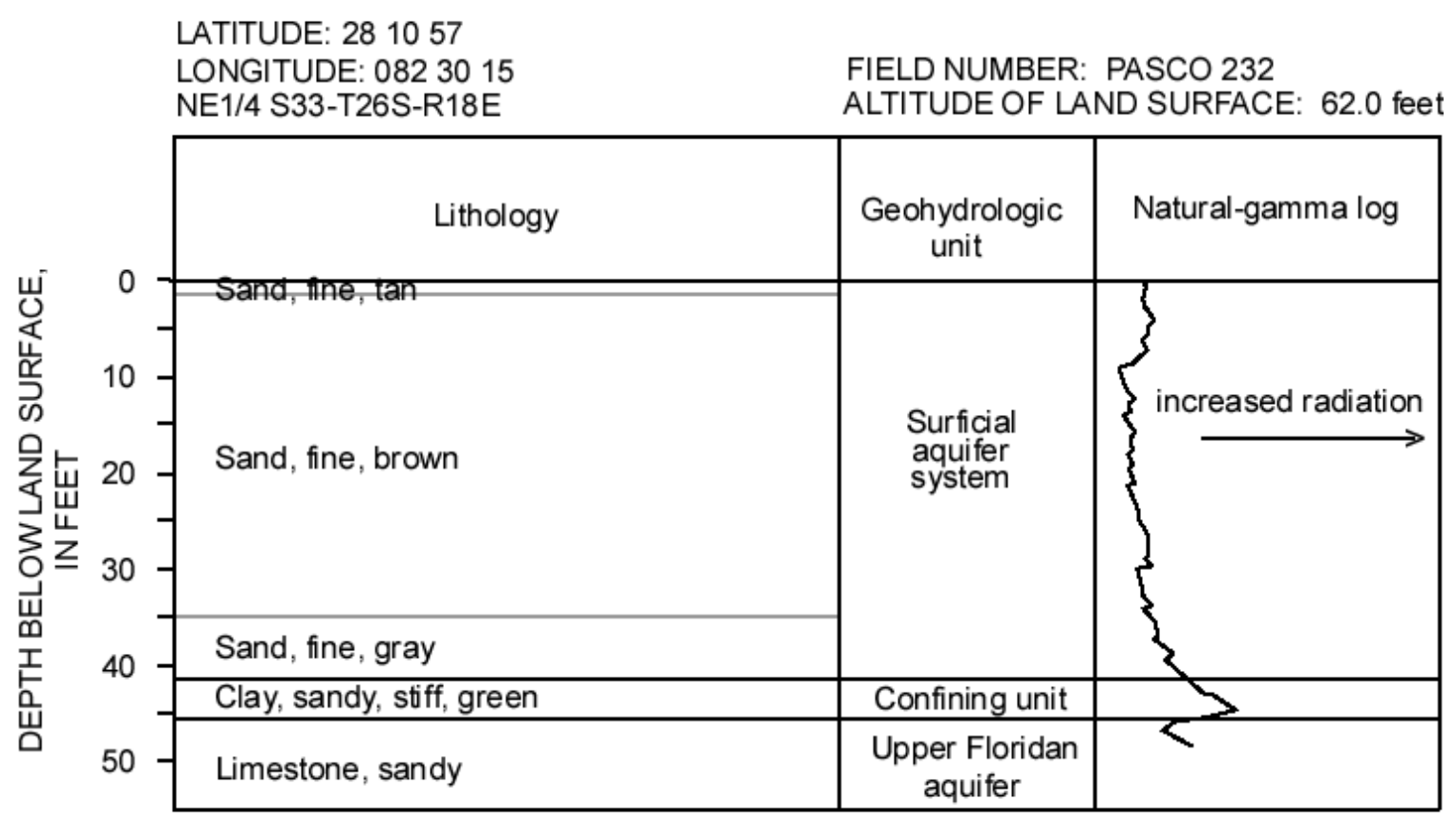

Two wells installed, screened intervals $12.5-17.5$ feet and $47.0-52.0$ feet. 
TEST-HOLE NUMBER 18

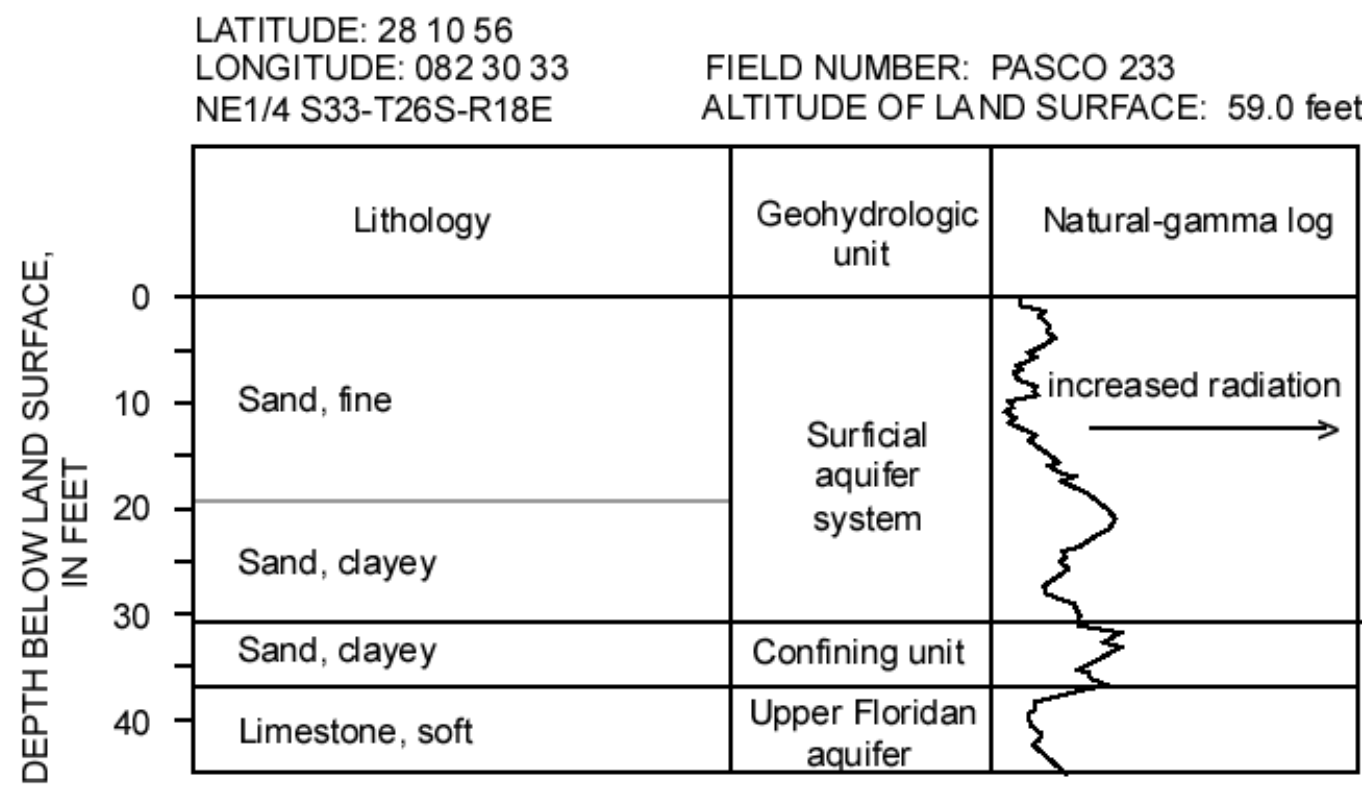

Two wells installed, screened intervals $12.0-17.0$ feet and $40.0-45.0$ feet. 


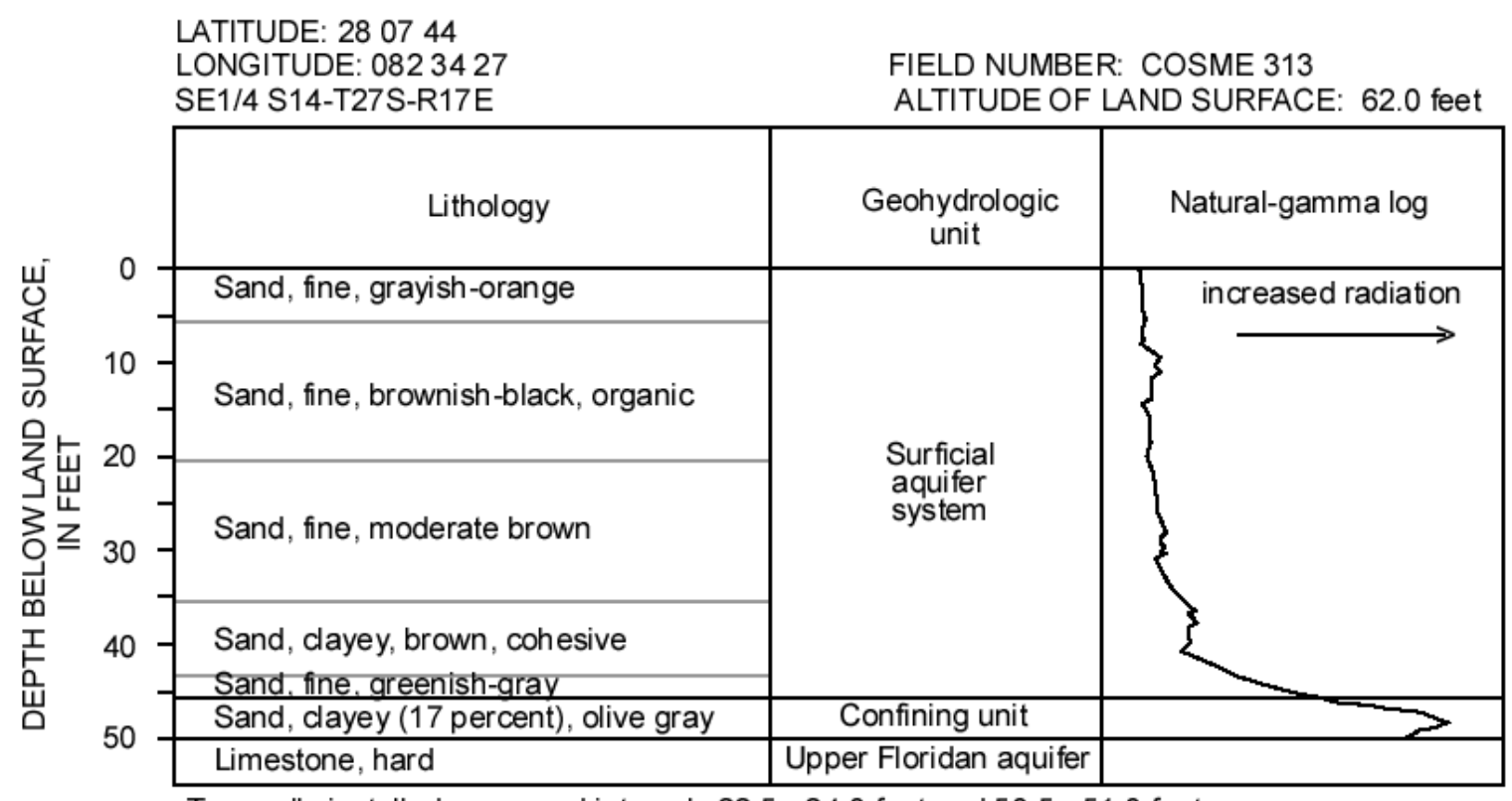

Two wells installed, screened intervals 22.5 - 24.0 feet and 50.5 - 51.0 feet.

Laboratory test results

\begin{tabular}{l|c}
\hline \multirow{2}{*}{\multicolumn{1}{c|}{ Parameter }} & Sample depth (feet) \\
\cline { 2 - 2 } & $49.0-49.5$ \\
\hline Vertical hydraulic conductivity (m/d) & 0.0026 \\
Median-grain size (mm) & .12 \\
Sorting coefficient & 1.7 \\
Specific gravity of solids & 2.62 \\
Effective porosity (percent) & 31.9 \\
Cation exchange capacity (MEQ/100g) & 4.6 \\
Quartz (percent) & 57 \\
Calcite (percent) & 0 \\
Feldspar (percent) & 6 \\
Kaolinite (percent) & 0 \\
Illite (percent) & 12 \\
Montmorillonite (percent) & 0 \\
Mixed-layer clays (percent) & 8 \\
\hline [m/d, meters per day; mm, millimeters; MEQ, milliequivalents; $g$ grams]
\end{tabular}


TEST-HOLE NUMBER 20

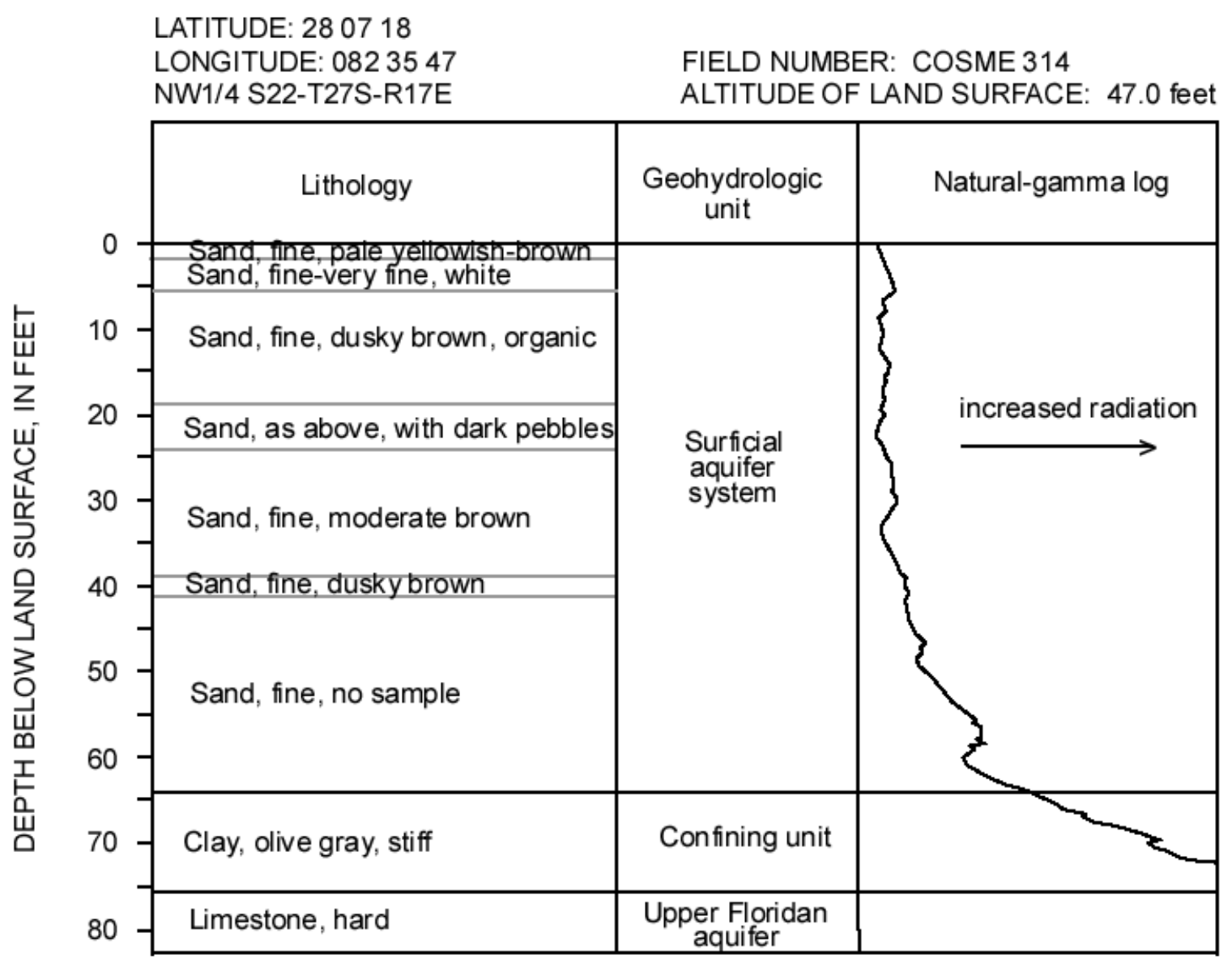

Two wells installed, screened intervals $16.0-17.5$ feet and $76.0-77.5$ feet. 


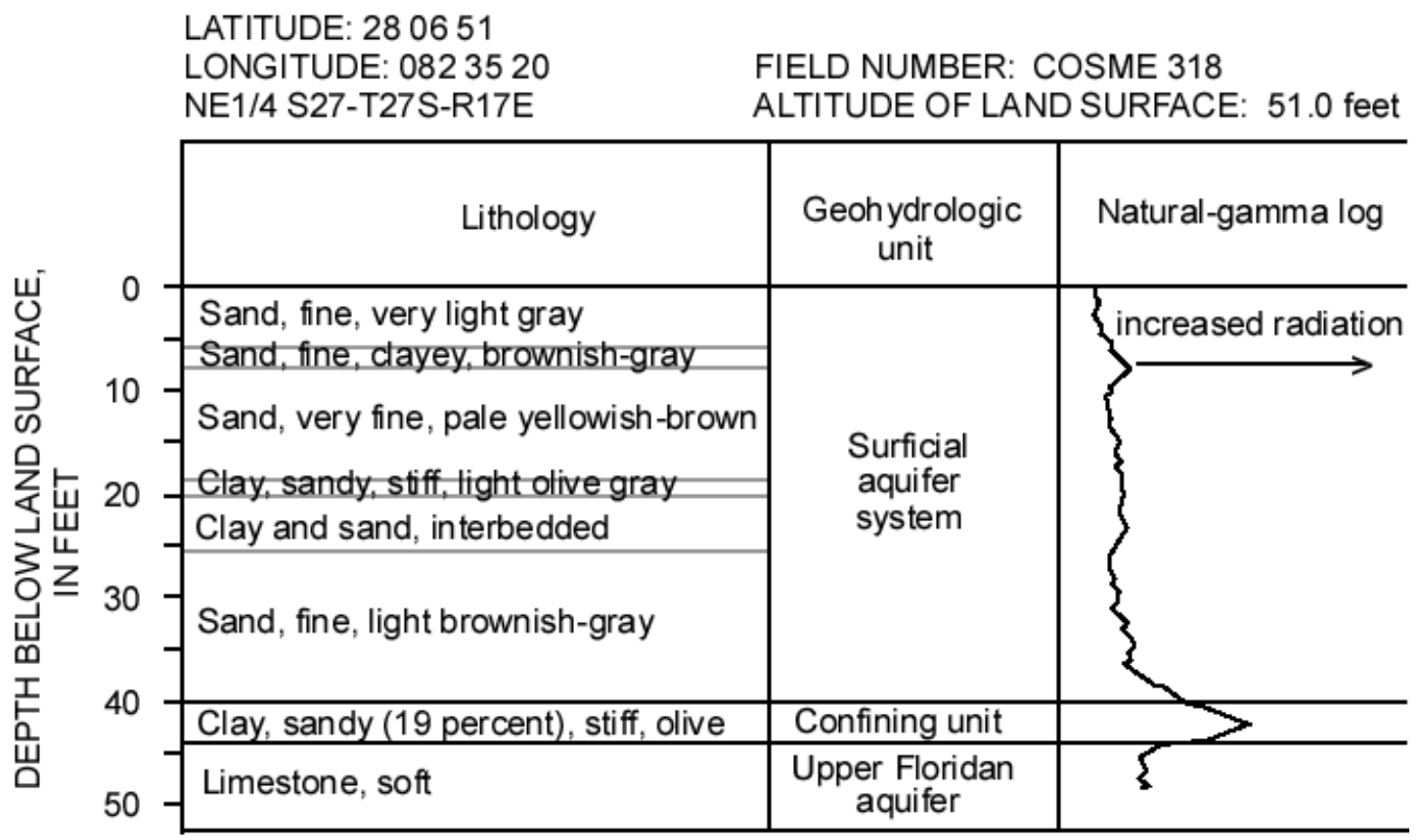

Two wells installed, screened intervals 17.0 - 18.5 feet and $47.5-48.5$ feet.

Laboratory test results

\begin{tabular}{l|c}
\hline \multirow{2}{*}{\multicolumn{1}{c|}{ Parameter }} & Sample depth (feet) \\
\cline { 2 - 2 } & $47.0-47.5$ \\
\hline Vertical hydraulic conductivity (m/d) & 0.00035 \\
Median-grain size (mm) & .004 \\
Sorting coefficient & -- \\
Specific gravity of solids & 2.68 \\
Effective porosity (percent) & 25.8 \\
Cation exchange capacity (MEQ/100g) & 17 \\
Quartz (percent) & 3 \\
Calcite (percent) & 76 \\
Feldspar (percent) & 1 \\
Kaolinite (percent) & 0 \\
Illite (percent) & 2 \\
Montmorillonite (percent) & 0 \\
Mixed-layer clays (percent) & 3 \\
\hline
\end{tabular}

[m/d, meters per day; mm, millimeters; MEQ, milliequivalents; $\mathrm{g}$, grams; --, no data] 
TEST-HOLE NUMBER 22

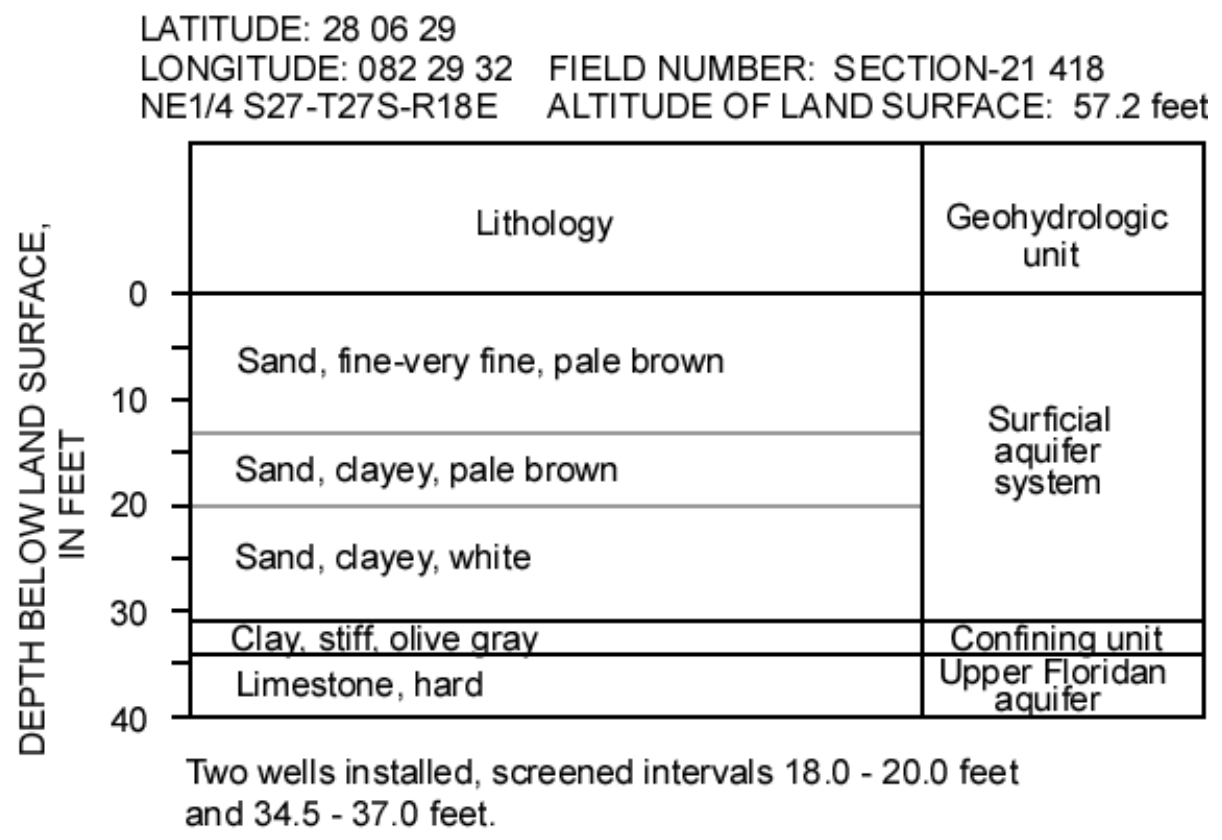




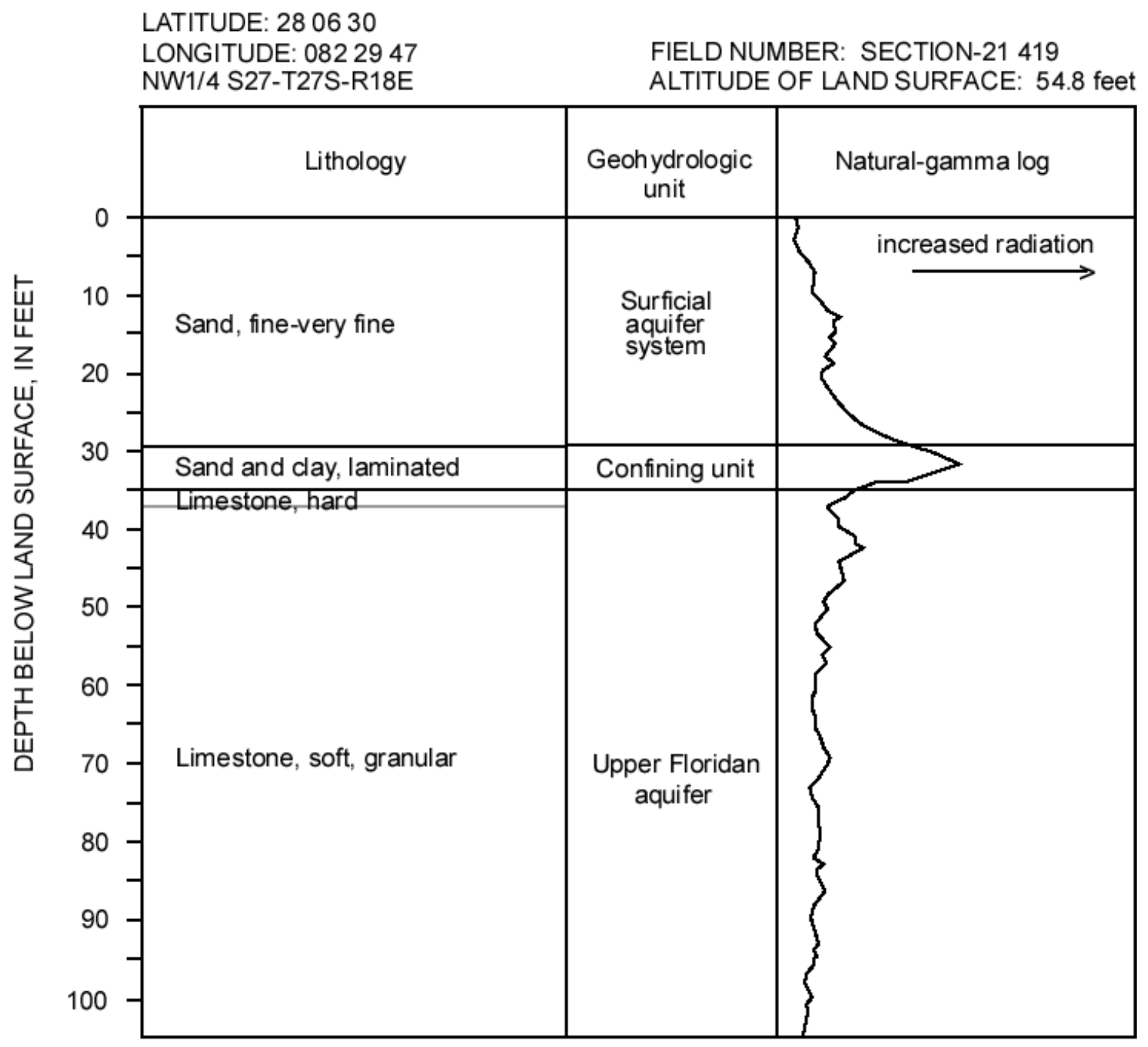

Two wells installed, screened intervals 18.5 - 20.0 feet and $103.0-105.0$ feet.

Note: Test hole was drilled near the edge of a topographic depression. Lithology is indicative of a relic sinkhole and does not represent regional conditions. 
LATITUDE: 281850

LONGITUDE: 0822213

FIELD NUMBER: CYPRESS CREEK 821

NE1/4 S14-T25S-R19E ALTITUDE OF LAND SURFACE: 76.9 feet

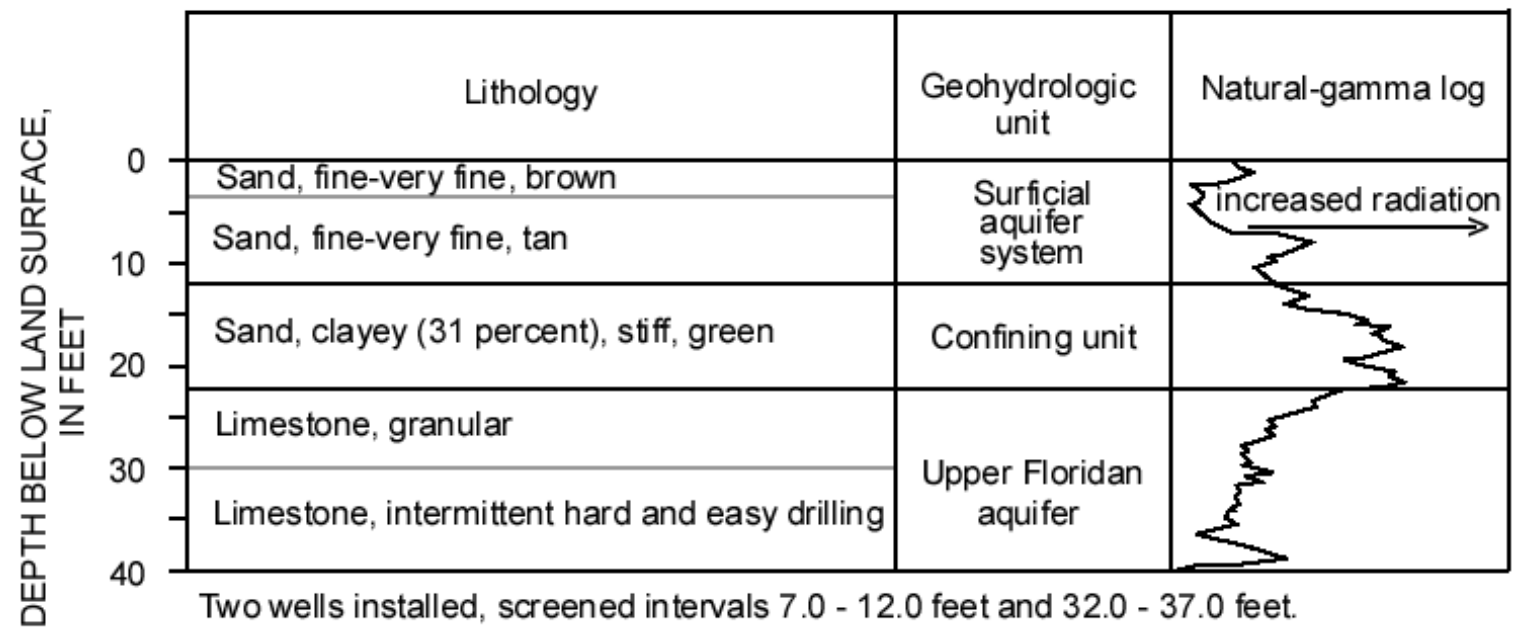

Laboratory test results

\begin{tabular}{l|c|c|c|c}
\hline \multirow{2}{*}{\multicolumn{1}{c|}{ Parameter }} & \multicolumn{4}{c}{ Sample depth (feet) } \\
\cline { 2 - 5 } & $2.0-2.5$ & $7.0-7.5$ & $17.0-17.5$ & $32.0-32.5$ \\
\hline Vertical hydraulic conductivity (m/d) & 0.11 & 0.61 & 0.00003 & 0.01 \\
Median-grain size (mm) & .13 & .15 & .08 & -- \\
Sorting coefficient & -- & 1.5 & -- & -- \\
Specific gravity of solids & 2.68 & 2.64 & 2.65 & -- \\
Effective porosity (percent) & 32.9 & -- & 22 & -- \\
Cation exchange capacity (MEQ/100g) & -- & -- & -- & -- \\
Quartz (percent) & -- & -- & 54 & 4 \\
Calcite (percent) & -- & -- & 0 & 86 \\
Feldspar (percent) & -- & -- & 3 & 0 \\
Kaolinite (percent) & -- & -- & 14 & 0 \\
Illite (percent) & -- & -- & 1 & 0 \\
Montmorillonite (percent) & -- & -- & 13 & 0 \\
Mixed-layer clays (percent) & -- & -- & 10 & 0 \\
\hline
\end{tabular}

[m/d, meters per day; mm, millimeters; MEQ, milliequivalents; g, grams; --, no data] 
TEST-HOLE NUMBER 25

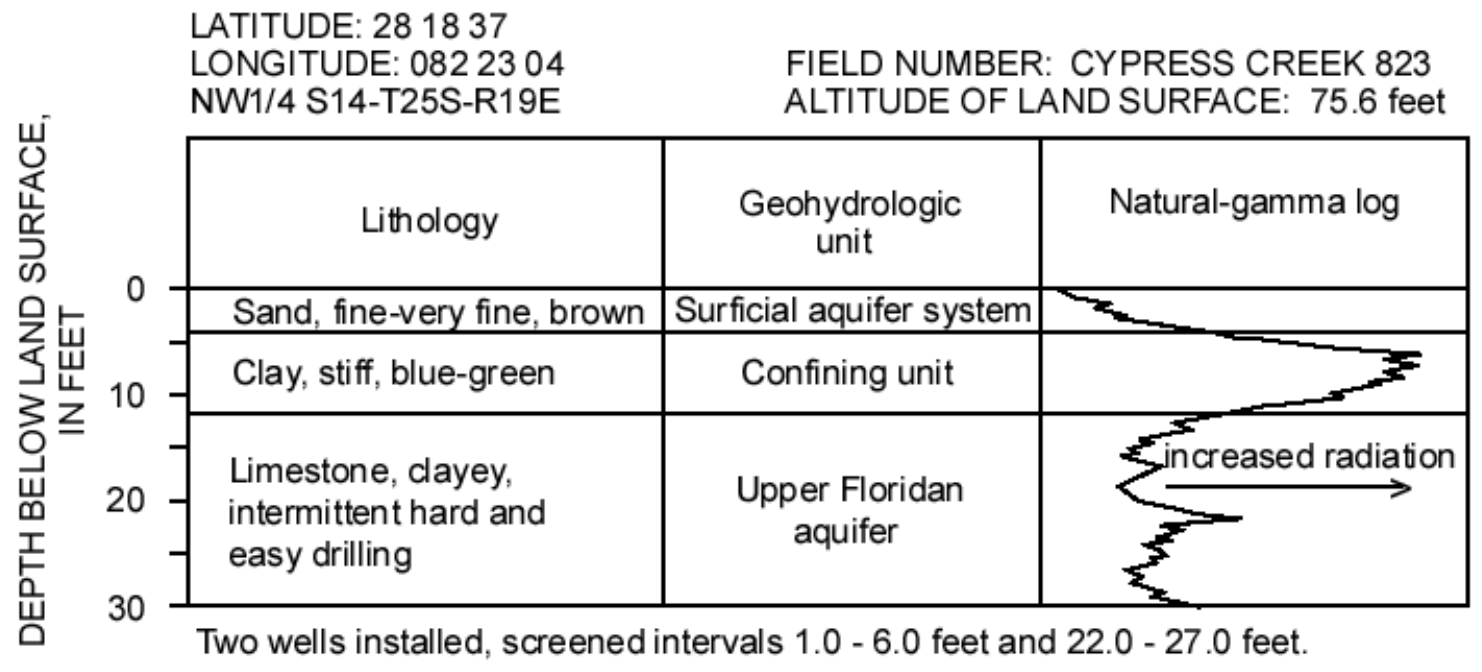


TEST-HOLE NUMBER 26

LATITUDE: 281723

LONGITUDE: 0822346

FIELD NUMBER: CYPRESS CREEK 826

SW1/4 S22-T25S-R19E ALTITUDE OF LAND SURFACE: 66.0 feet

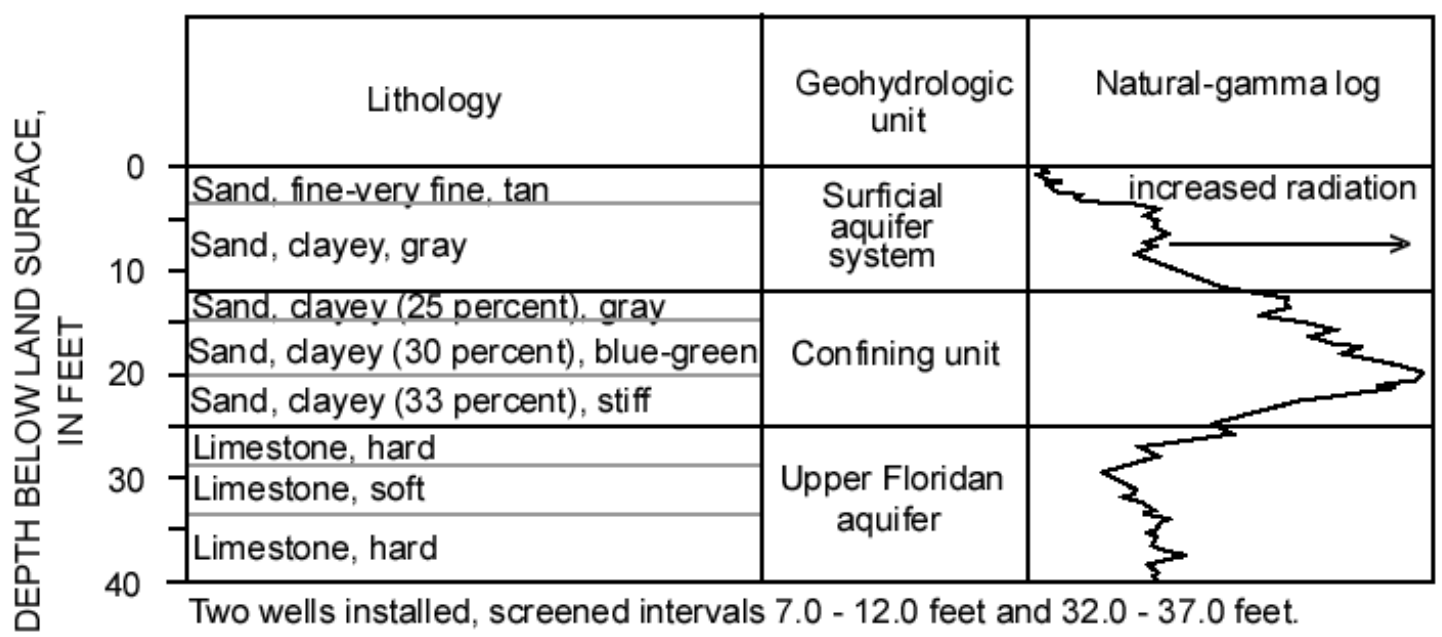

Laboratory test results

\begin{tabular}{l|c|c|c|c}
\hline \multirow{2}{*}{\multicolumn{1}{c|}{ Parameter }} & \multicolumn{5}{c}{ Sample depth (feet) } \\
\cline { 2 - 5 } & $2.0-2.5$ & $12.0-12.5$ & $17.0-17.5$ & $22.0-22.5$ \\
\hline Vertical hydraulic conductivity (m/d) & 0.77 & 0.00007 & -- & 0.00007 \\
Median-grain size (mm) & .13 & .1 & .08 & .07 \\
Sorting coefficient & -- & .15 & 3.2 & -- \\
Specific gravity of solids & 2.66 & 2.64 & -- & 2.59 \\
Effective porosity (percent) & 35.7 & 19.4 & -- & 19.1 \\
Cation exchange capacity (MEQ/100g) & -- & -- & -- & -- \\
Quartz (percent) & -- & -- & 58 & -- \\
Calcite (percent) & -- & -- & 0 & -- \\
Feldspar (percent) & -- & -- & 3 & -- \\
Kaolinite (percent) & -- & -- & 0 & -- \\
Illite (percent) & -- & -- & 0 & -- \\
Montmorillonite (percent) & -- & -- & 14 & -- \\
Mixed-layer clays (percent) & -- & -- & 26 & -- \\
\hline
\end{tabular}

[m/d, meters per day; mm, millimeters; MEQ, milliequivalents; g, grams; --, no data] 


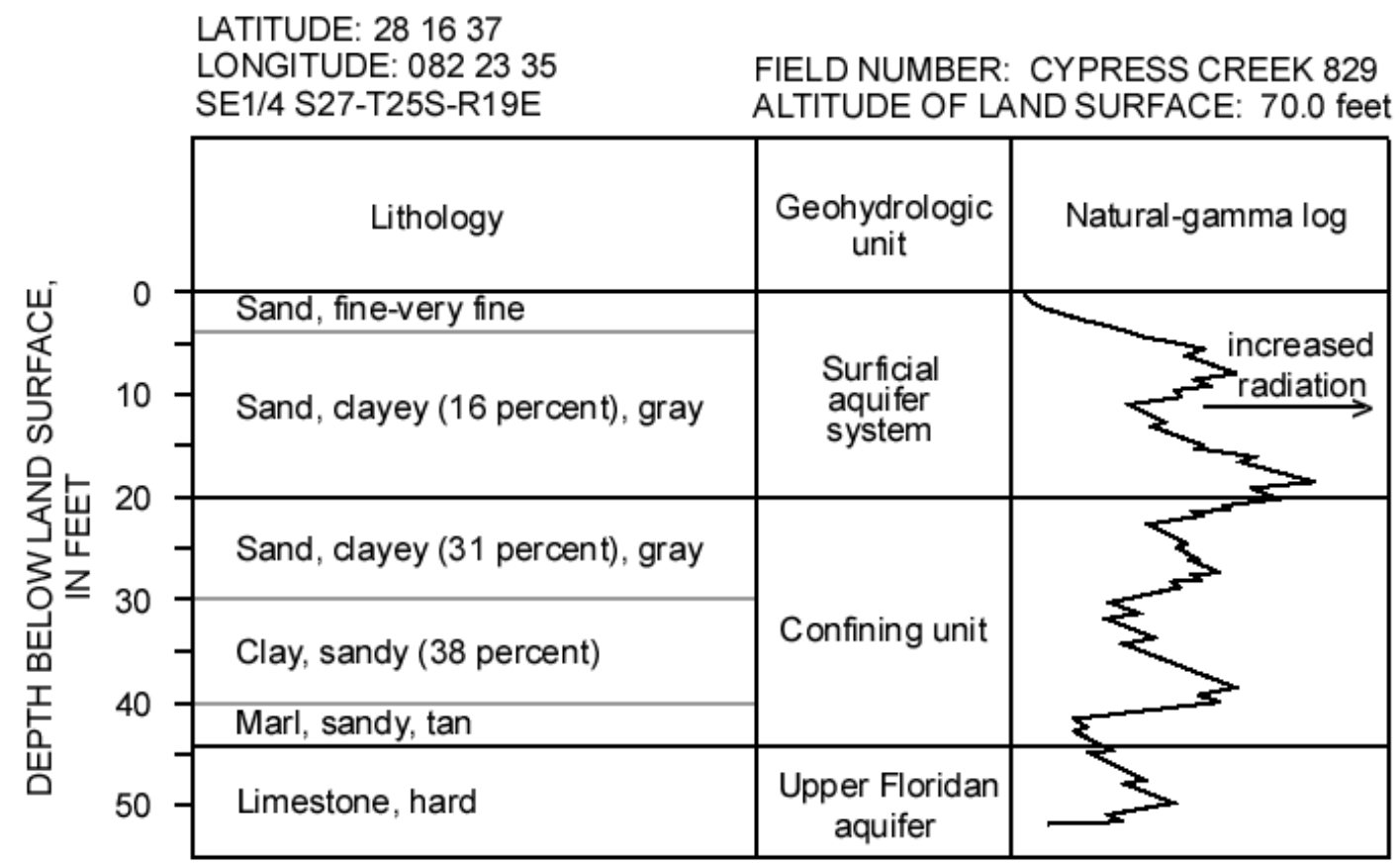

Two wells installed, screened intervals $8.0-13.0$ feet and $49.0-52.0$ feet.

Laboratory test results

\begin{tabular}{l|c|c|c|c}
\hline \multirow{2}{*}{ Parameter } & \multicolumn{4}{c}{ Sample depth (feet) } \\
\cline { 2 - 5 } & $12.0-12.5$ & $22.0-22.5$ & $32.0-32.5$ & $42.0-42.5$ \\
\hline Vertical hydraulic conductivity (m/d) & 0.029 & 0.0011 & 0.0000006 & 0.0016 \\
Median-grain size (mm) & .09 & .07 & .03 & -- \\
Sorting coefficient & 2.3 & -- & -- & -- \\
Specific gravity of solids & 2.67 & 2.63 & 2.65 & -- \\
Effective porosity (percent) & 17 & 16.4 & 12.8 & -- \\
Cation exchange capacity (MEQ/100g) & -- & -- & -- & -- \\
Quartz (percent) & -- & -- & 46 & 28 \\
Calcite (percent) & -- & -- & 0 & 45 \\
Feldspar (percent) & -- & -- & 5 & 2 \\
Kaolinite (percent) & -- & -- & 0 & 0 \\
Illite (percent) & -- & -- & 5 & 0 \\
Montmorillonite (percent) & -- & -- & 27 & 0 \\
Mixed-layer clays (percent) & -- & -- & 15 & 8 \\
\hline
\end{tabular}

[m/d, meters per day; mm, millimeters; MEQ, milliequivalents; g, grams; --, no data] 


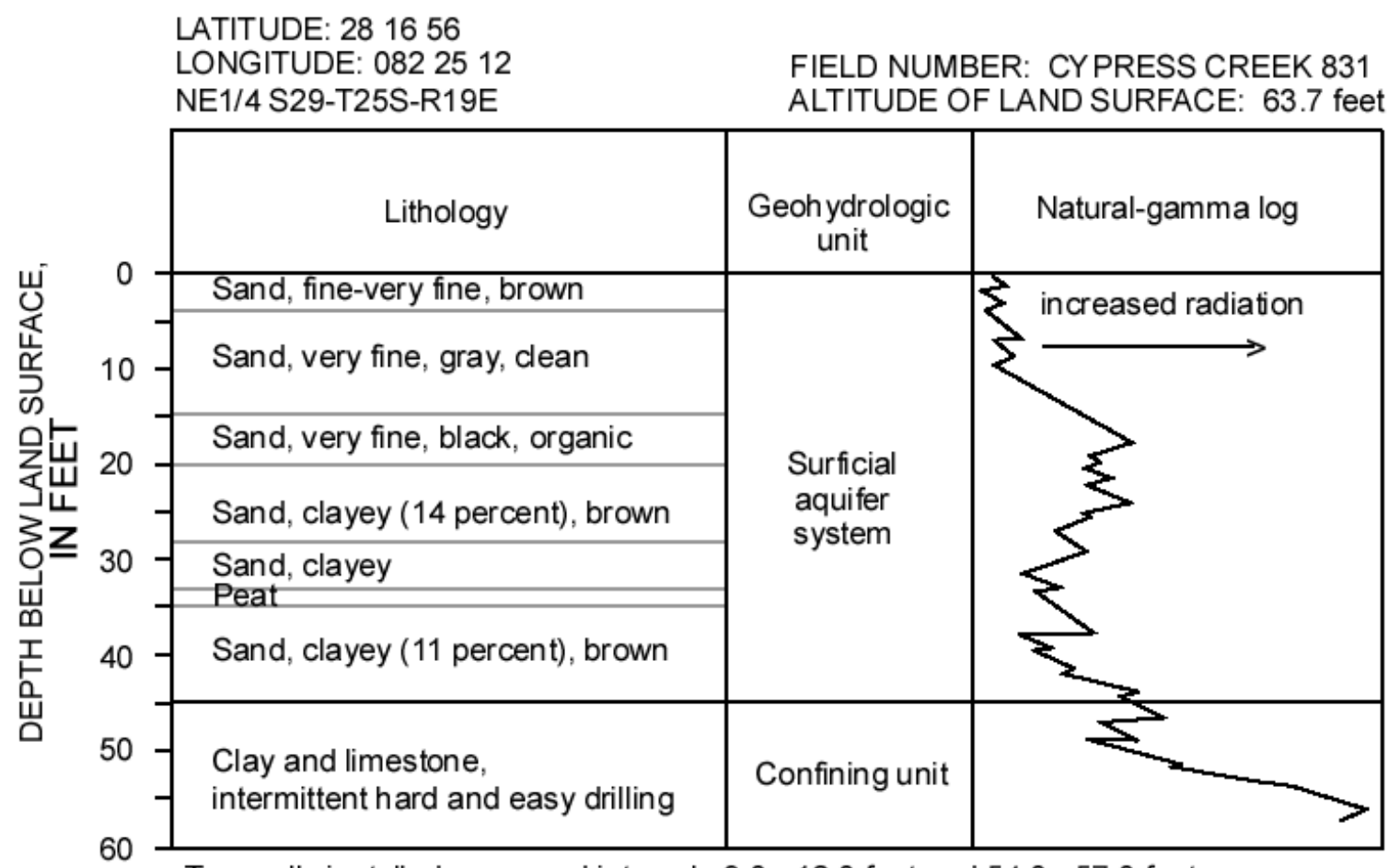

Two wells installed, screened intervals $9.0-12.0$ feet and $54.0-57.0$ feet.

Laboratory test results

\begin{tabular}{l|c|c|c|c}
\hline \multirow{2}{*}{\multicolumn{1}{c|}{ Parameter }} & \multicolumn{4}{c}{ Sample depth (feet) } \\
\cline { 2 - 5 } & $7.0-7.5$ & $17.0-17.5$ & $37.0-37.5$ & $47.0-47.5$ \\
\hline Vertical hydraulic conductivity (m/d) & 1.9 & 0.088 & 0.0052 & 0.0018 \\
Median-grain size (mm) & .1 & .1 & .11 & -- \\
Sorting coefficient & 1.3 & 1.3 & 1.5 & -- \\
Specific gravity of solids & 2.68 & 2.66 & 2.67 & -- \\
Effective porosity (percent) & 33.9 & 32.8 & 24.2 & -- \\
Cation exchange capacity (MEQ/100g) & -- & -- & -- & -- \\
Quartz (percent) & -- & -- & 78 & 2 \\
Calcite (percent) & -- & -- & 0 & 89 \\
Feldspar (percent) & -- & -- & 0 & 0 \\
Kaolinite (percent) & -- & -- & 32 & 0 \\
Illite (percent) & -- & -- & 0 & 0 \\
Montmorillonite (percent) & -- & -- & 0 & 0 \\
Mixed-layer clays (percent) & -- & -- & 0 & 5 \\
\hline
\end{tabular}

[m/d, meters per day; mm, millimeters; MEQ, milliequivalents; g, grams; --, no data] 
TEST-HOLE NUMBER 29

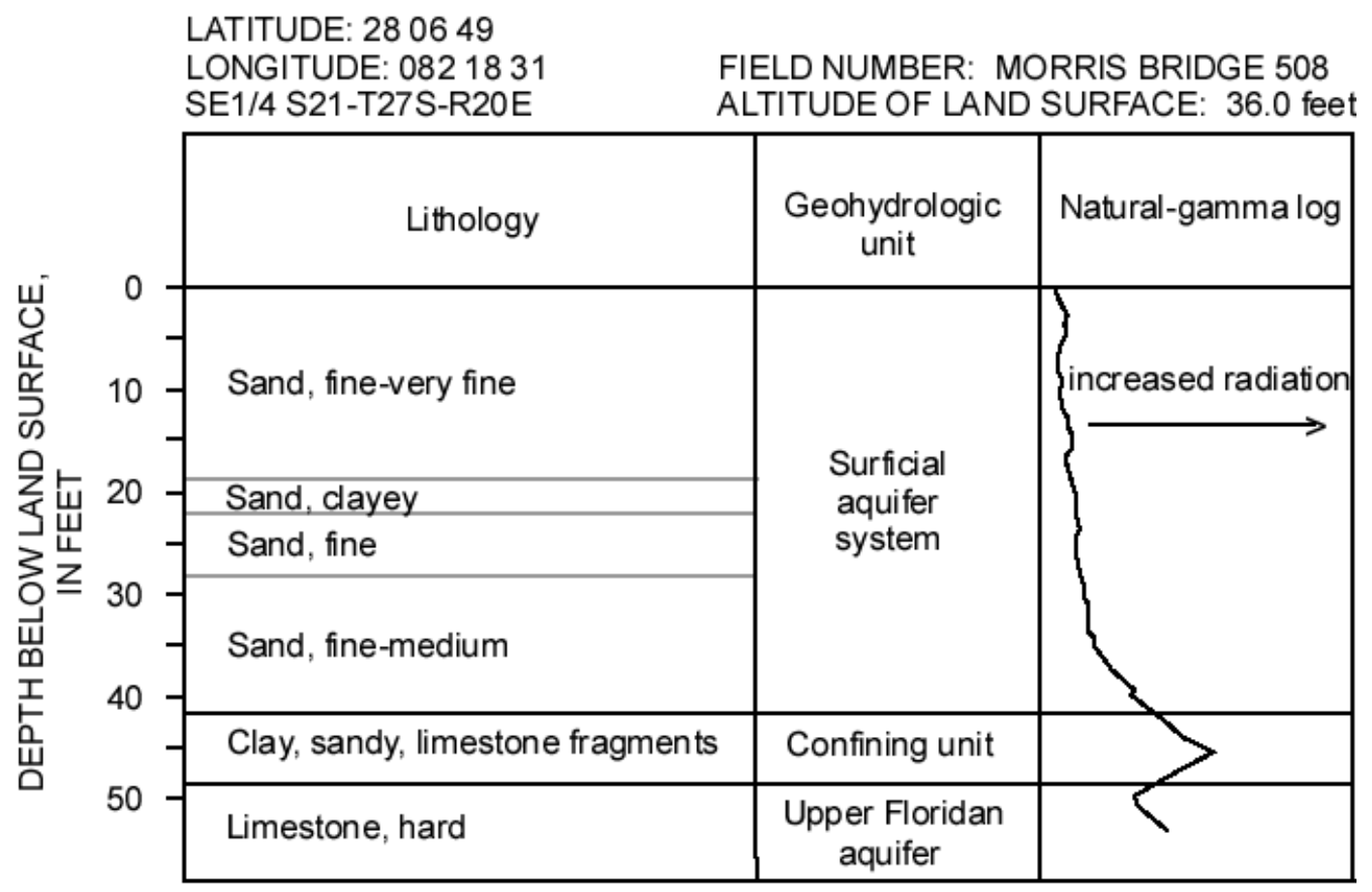

Two wells installed, screened intervals $13.0-14.0$ feet and $53.0-54.0$ feet. 
TEST-HOLE NUMBER 30

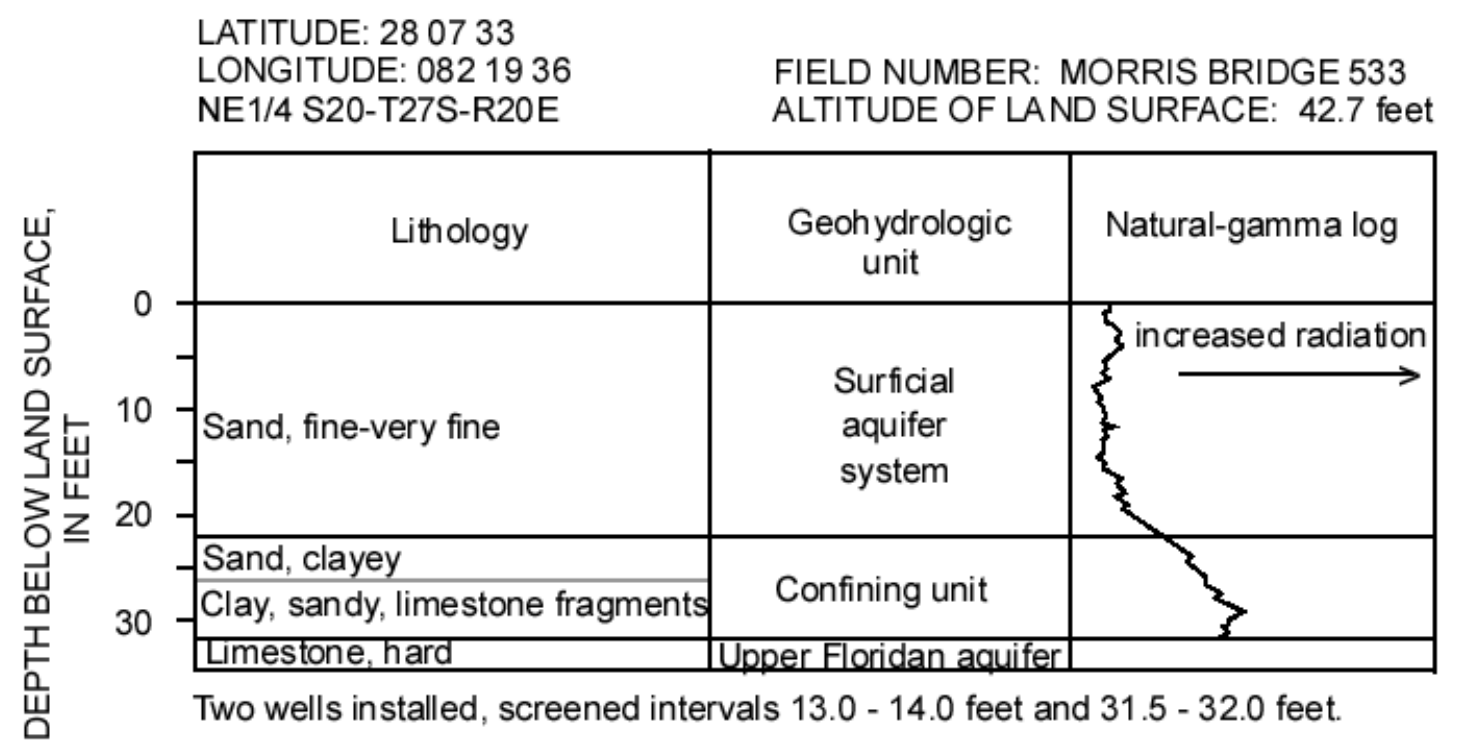


TEST-HOLE NUMBER 31

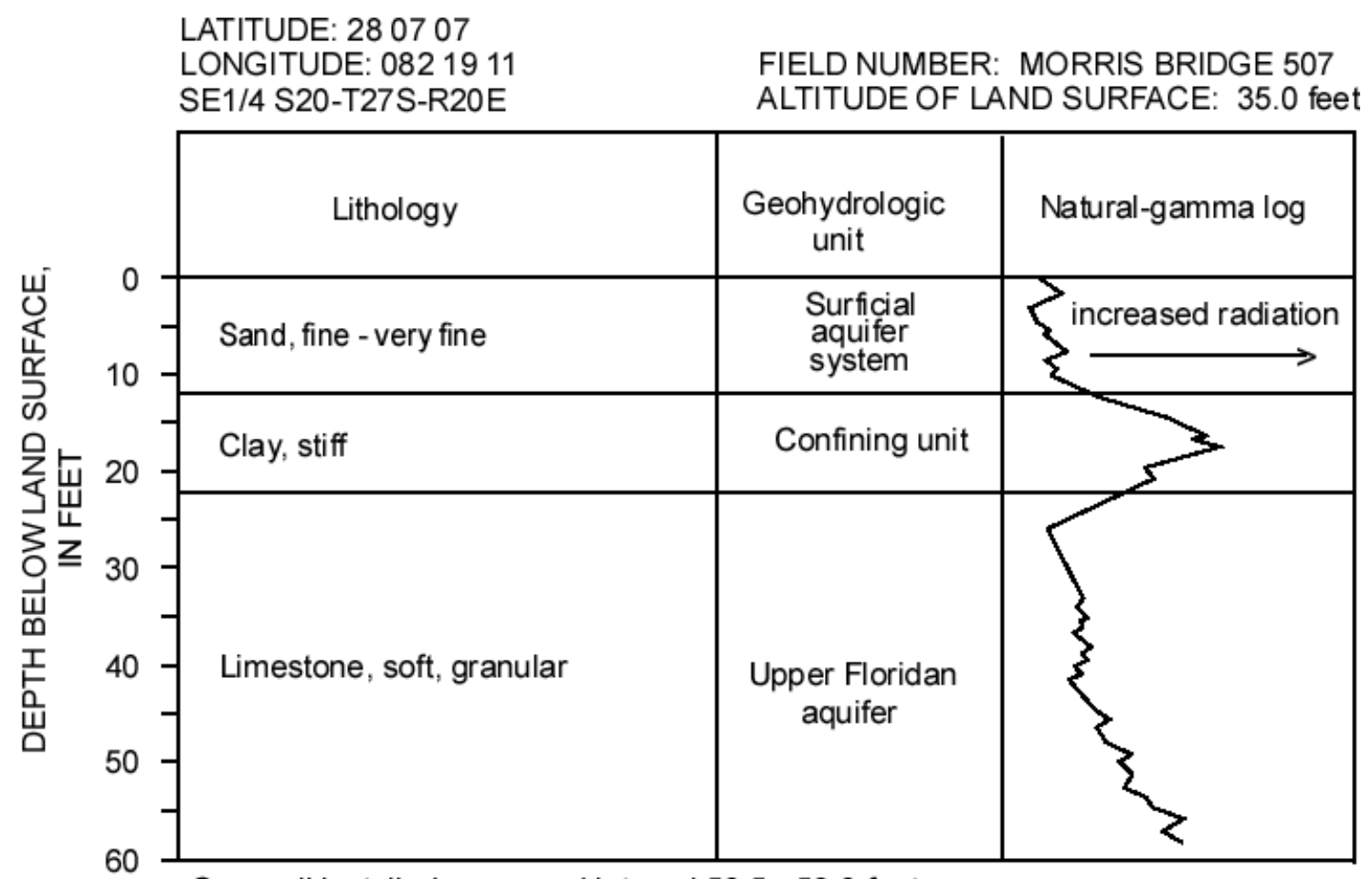

One well installed, screened interval 58.5 - 59.0 feet. 
TEST-HOLE NUMBER 32

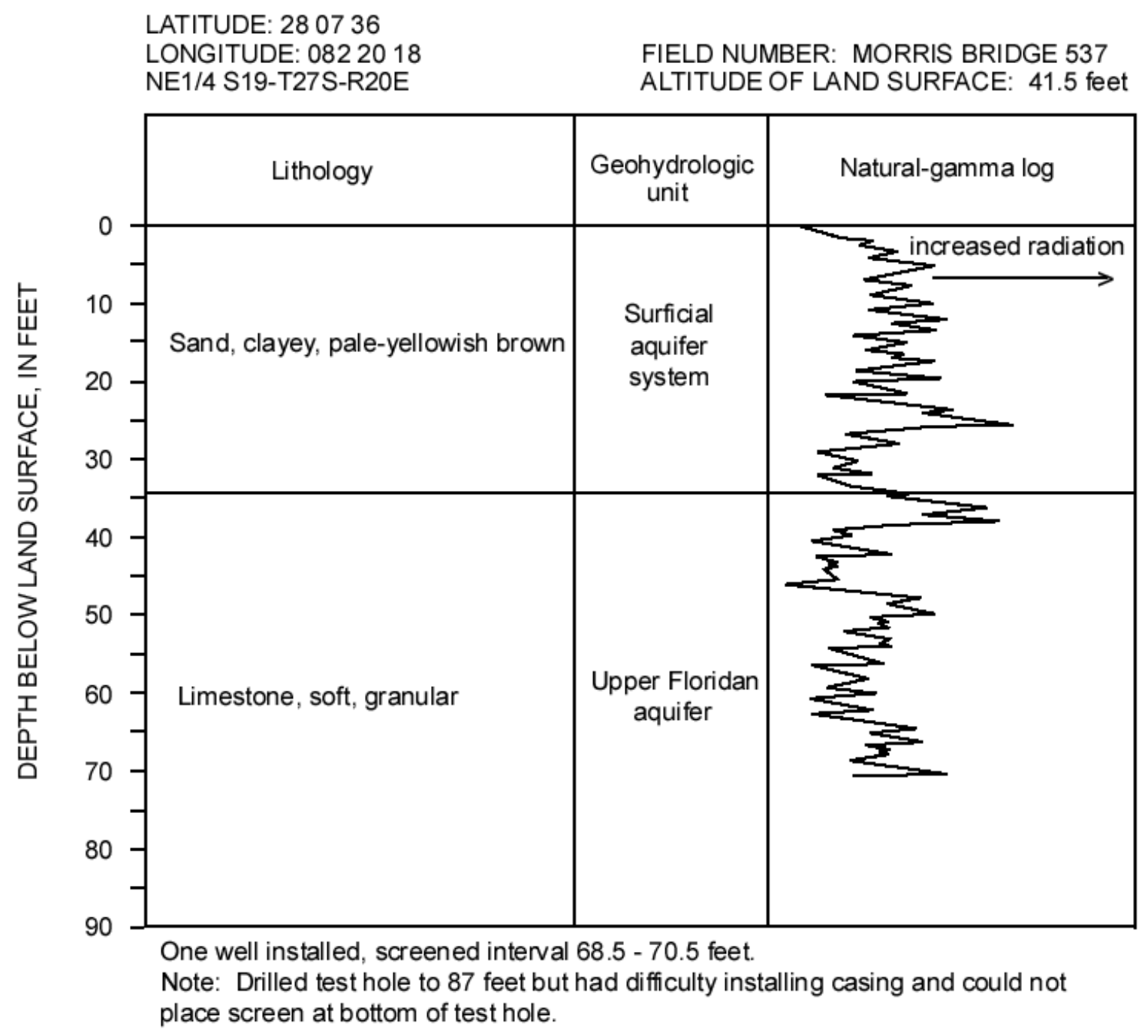

